Historic, Archive Document

Do not assume content reflects current scientific knowledge, policies, or practices. 

A99.9 COR/STA

F76324
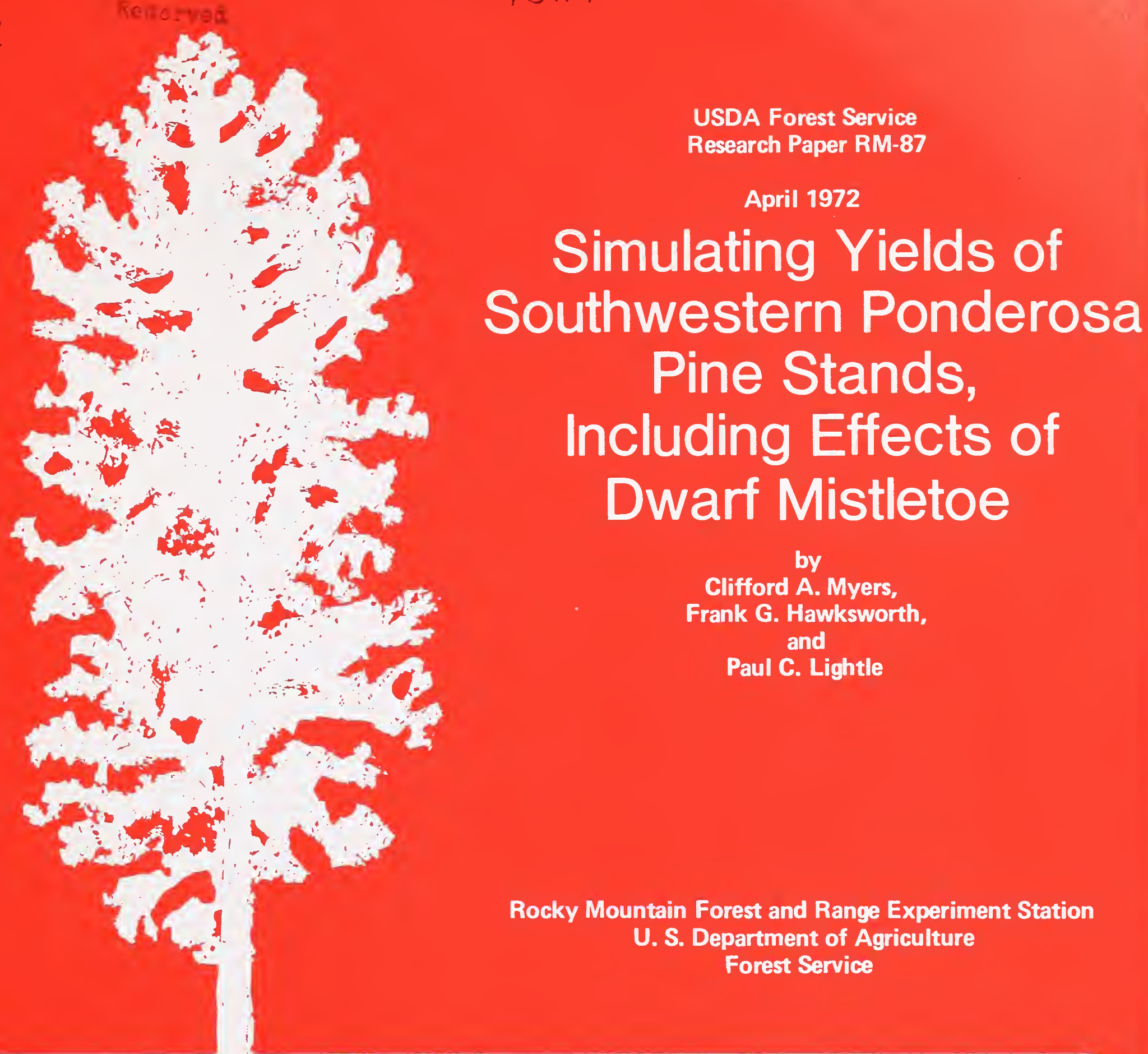

USDA Forest Service

Research Paper RM-87

April 1972

की

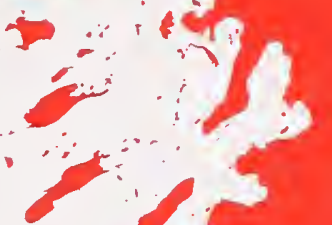

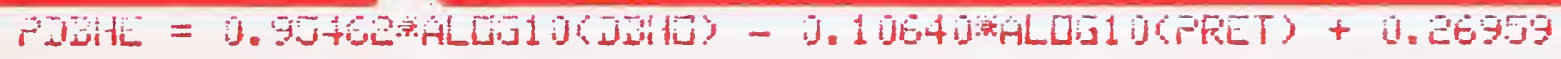

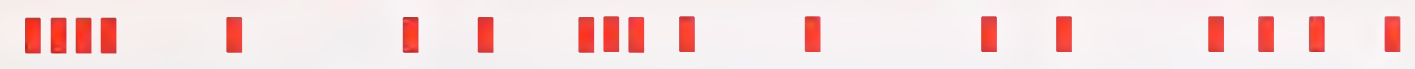
】
111
【11

11

\author{
by
}

Clifford A. Myers,

Frank G. Hawksworth, and

Paul C. Lightle

Rocky Mountain Forest and Range Experiment Station

U. S. Department of Agriculture

Forest Service

0000000000000000000000000000000000000000000000000000000000000000000000000

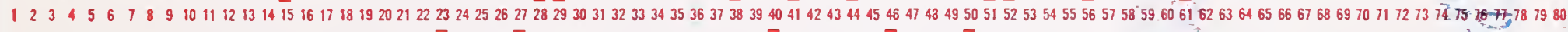
$1111111111111111111111] 111] 111111111111] 11111] 111] 111111111111111111111111$ t17111 $22222222 \square 22222222222 \square 222222222 \rrbracket 2222222222222222222222222222222 \rrbracket 22222222222222222$

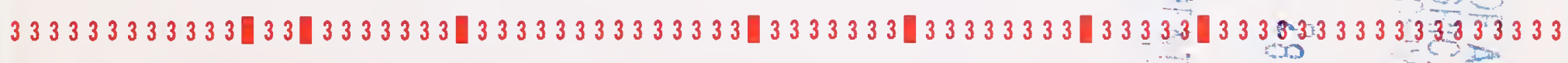

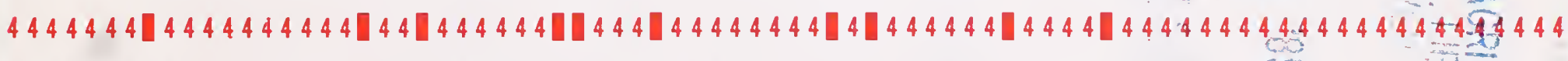

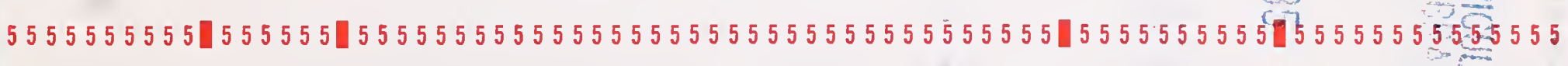
$6666666666666666666 \square 6666 \square 6666666 \square 66666666 \square 66666 \square 666666666666666 \square 66666666666666666$ $777777777777777777777771777777777777777777777177177777777777777777777717]^{7}$

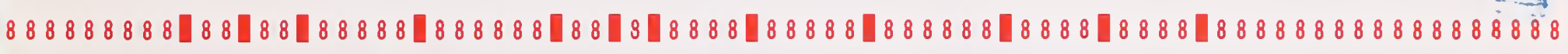




Abstract
Presents a procedure for computation of yield tables for
diseased even-aged stands of ponderosa pine in Arizona and New
Mexico. Stand age at time of initial infection by dwarf mistletoe
may be varied as desired. Other control variables include stand
age at initial thinning, stocking goals, frequency of thinning,
and regeneration system. Stand conditions and severity of dwarf
mistletoe infestation change with time and in response to inter-
mediate cuttings.
Keywords: Stand yield tables, timber management, forest manage-
ment, simulation, Arceuthobium vaginatum, Pinus ponderosa.




\title{
Simulating Yields of Southwestern Ponderosa Pine Stands, Including Effects of Dwarf Mistletoe
}

\author{
by \\ Clifford A. Myers, Principal Mensurationist, \\ Frank G. Hawksworth, Principal Plant Pathologist, \\ and \\ Paul C. Lightle, Principal Plant Pathologist \\ Rocky Mountain Forest and Range Experiment Station'
}

'Forest Service, U. S. Department of Agriculture, with central headquarters maintained at Fort Collins, in cooperation with Colorado State University. Lightle is stationed at Albuquerque, in cooperation with the University of New Mexico. 


\section{Contents}

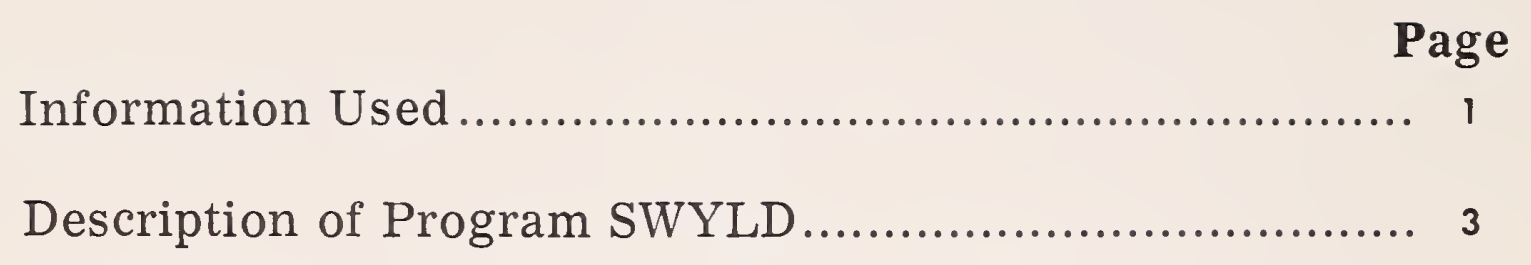

A Sample Problem.............................................. 6

Literature Cited............................................ $\quad 7$

Appendices:

1. Listing of Program SWYLD .......................... 8

2. Output of Sample Problem .......................... 12 


\title{
Simulating Yields of Southwestern Ponderosa Pine Stands, Including Effects of Dwarf Mistletoe
}

\author{
Clifford A. Myers, Frank G. Hawksworth, and Paul C. Lightle
}

Computation procedures for predicting yields and a computer program SWYLD that prints yield tables are described for even-aged stands of southwestern ponderosa pine (Pinus ponderosa Laws.). Details of field work and computations that apply to healthy stands of ponderosa pine have been presented elsewhere (Myers 1971). Such procedures will not, however, provide some items of information essential for decisionmaking in the Southwest. For practical application, important and predictable causes of reduced growth and mortality should be included in the computations. One such cause is included here.

Dwarf mistletoe (Arceuthobium vaginatum subsp. cryptopodum (Engelm.) Hawks. \& Wiens) is widespread in southwestern ponderosa pine forests. Andrews and Daniels (1960) found this dwarf mistletoe on 36 percent of some 2,700 ponderosa pine plots located throughout Arizona and New Mexico. In the Lincoln National Forest and adjacent Mescalero Apache Reservation in southern New Mexico, the infection rate was over 50 percent (Andrews and Daniels 1960, Hawksworth and Lusher 1956).

Several studies have documented the adverse effects of dwarf mistletoe on the height and diameter growth of individual ponderosa pines (Korstian and Long 1922, Sperry 1934, Hawksworth 1961). Such studies do not, however, reveal the total stand loss due to dwarf mistletoe. They do not report mortality, but give information on surviving trees only.

Dwarf mistletoe is one of the four major causes of mortality in southwestern ponderosa pine (Myers and Martin 1963, Pearson 1939). Pearson (1938) found mortality in heavily infested cutover stands to be about five times that in comparable lightly infested or healthy stands. On the Mescalero Apache Reservation, New Mexico, mortality in stands with dwarf mistletoe was nearly twice as high in infested stands as in healthy stands (Hawksworth and Lusher 1956). The differences were most pronounced in cutover areas, where the mortality rate in infested stands was 3.3 times that in mistletoe-free stands.

In the all-aged stands of Grand Canyon National Park, mistletoe-caused mortality and growth reduction offset 10-year basal area growth in moderately and heavily infested stands
(Lightle 1966). In pole-sized stands on the Mescalero Reservation, however, basal area declined during a comparable period only in heavily infested stands.

The studies referred to above dealt primarily with the cumulative effects of dwarf mistletoe in unmanaged stands. They do not provide data that can be used directly for yield prediction in managed stands or for comparisons of alternatives. To obtain the necessary pine-mistletoe relationships, procedures used in lodgepole pine stands (Myers, Hawksworth, and Stewart 1971) were repeated in the Southwest.

\section{Information Used}

Field and office procedures used to obtain the relationships in program SWYLD were similar to those outlined by Myers (1971) for healthy stands. Additional information on pine-dwarf mistletoe interactions was obtained from several temporary and permanent plots. Most data were from a yield study ${ }^{2}$ based on 55 transects located throughout the ponderosa pine forests of Arizona and New Mexico. Additional information was obtained from permanent plots at Fort Valley Experimental Forest and Grand Canyon, Arizona, and the Mescalero Apache Reservation, New Mexico. Derivations of functions that include measures of infection by dwarf mistletoe are described briefly below and in detail elsewhere (Myers et al. 1971).

Basal area and other per-acre values, average stand diameter, and site index (Meyer 1938) are used as dependent and independent variables to obtain the prediction equations used in program SIVYLD (appendix 1). The equations shown as FORTRAN statements in the program listing contain only significant ind ependent variables. They indicate the possible appearance of similar functions for other species or localities.

Items computed from field data and uses made of them in SWYLD are as follows:

\footnotetext{
${ }^{2}$ Hawksworth, F. G., P. C. Lightle, and T. E. Hinds. Effects of dwarf mistletoe on growth and yields of ponderosa pine. (Manuscript in preparation at Rocky Mt. Forest and Range Exp. Stn.)
} 
1. Equations to estimate mortality in healthy (OUT) and diseased (DIE) stands are computed from density, mortality, and other data.

2. Prediction equations for height (HTSO) are determined from healthy stands with densities within the range of possible management goals. Infected plots provide data used to derive the equation for reduction in height growth due to disease (PCT).

3. Initial average diameters and other variables from healthy stands are used to obtain the equation for average d.b.h. after 10 years (DBHO). Data from diseased stands provide the equation for reduction in diameter growth due to dwarf mistletoe (TEM). Average stand diameter is the diameter of the tree of average basal area.

4. Cubic- and board-foot volumes per acre are computed from tree volume equations (Myers 1963). Total cubic volumes then provide equations for stand volume in cubic feet (TOTO and TOTT). Total volumes plus merchantable cubic- and board-foot volumes are used to obtain equations for the volume conversion factors (FCTR and PROD) computed by subroutine SWVOL.

5. Several prediction equations are used to obtain dwarf mistletoe ratings (DMR) in SWYLD. One equation for DMR predicts the initial rating if the stand has never been thinned. Other equations for DMR predict the current rating as an increase from a past value. An expected post-thinning rating (DMRT) is computed if infection index is not so high (3.0 or greater) as to make thinning impractical, and if the stand has not already been thinned from above. An equation in subroutine SWCUT2 then predicts the percentage of trees to be removed by thinning from above (REDT) to obtain the expected rating. For subsequent thinnings, DMRT is computed from intensity of thinning and rating prior to thinning.

Computation of ratings by SWYLD begins with use of the variable START. This is the average of the tree ages when each part of the stand is first infected. It is not the age when the first tree in the stand is infected.

6. Thinning intensity in healthy stands, or in stands to be thinned from below, is based on a relationship between d.b.h. and basal area. Basis for the computations is given in the following tabulation:

Average stand
d.b.h. after
thinning
(Inches)

2.0

2.5

3.0

3.5

4.0

4.5

5.0

5.5

6.0

6.5

7.0

7.5

8.0

8.5

9.0

9.5

$10.0+$

\section{Basal area per acre (Sq. ft.)}

12.1

17.9

23.7

29.5

35.2

41.0

46.8

51.8

56.6

61.2

65.4

69.2

72.5

75.3

77.5

79.1

80.0
These values, SQFT in subroutine SWCUT1 and SWCUT3, represent one possible series of densities that could be used to guide successive thinnings. The growing stock level shown above is 80 ; reserve basal area remains constant at 80 square feet after stand d.b.h. reaches 10.0 inches. Other stocking levels are named the same way. For example, level 100 means that reserve basal area will be 100 square feet when d.b.h. is 10.0 inches or larger. Basal area for level 100 and diameters smaller than 10.0 inches are obtained by multiplying each basal area of level 80 by the amount $100 / 80$. Values for any stocking level, THIN or DLEV in SWYLD, are computed similarly.

Equations for DBHP in subroutine SWCUT1 and SWCUT3 also describe the tabulated values. In this case, diameter is estimated when basal area and the desired stocking level are known. Variables BREAK and BUST indicate points where the relationship of diameter on basal area has been broken into segments for convenience in regression analysis.

Growing stock levels to be left after thinning from below are indicated by assigning values to THIN and DSTY on data card type 4, as shown in the listing of Order and Contents of the Data Deck. Each assigned value is a growing stock level or the basal 
area left when d.b.h. after thinning is 10.0 inches or greater.

7. Equations for DBHE (used as DBHT) in SWCUT1 and SWCUT3 and for ADDHT in the main routine are derived from data obtained in a variety of thinned stands. Thinnings could also be simulated on a computer to obtain data for the DBHE and ADDHT equations (Myers 1971).

8. Values for AGEO, DBHO, and DENO on data card type 4 are obtained by examining numerous young stands. Average d.b.h. at various ages is determined for each site class and for each of several levels of stand density. These data are gathered by users of the program to partially describe their management objectives.

\section{Description of Program SWYLD}

Program SWYLD consists of a main program and four subroutine subprograms. The main program performs most computations and writes the yield tables. Three subroutines compute average stand d.b.h. and stand density after thinning. The fourth subroutine computes factors that are used in the main program to convert total cubic feet to other units.

Operations performed by each routine are identified by the comment statements of the source program (appendix 1). Initial stand conditions and values of several control variables are read into computer memory in the order and format given in the tabulation of Order and Contents of the Data Deck. Zero punches in any data card except card type 5 will cause control to move to the end of the program, a diagnostic message to be printed, and termination of the job. The number of yield tables computed and printed is determined by the values assigned NTSTS on card type 1 and MIX on card type 3. NTSTS is the number of sets of tables to be produced. MIX is the number of tables in a set or the number of growing stock levels (DLEV) tested.

Order and Contents of the Data Deck

\begin{tabular}{|c|c|c|c|c|c|}
\hline $\begin{array}{l}\text { Card } \\
\text { type }\end{array}$ & $\begin{array}{l}\text { Number of } \\
\text { cards }\end{array}$ & $\begin{array}{c}\text { Variable } \\
\text { name }\end{array}$ & Columns & Format & Description of variable \\
\hline 1 & 1 & NTSTS & $1-4$ & I4 & $\begin{array}{l}\text { Number of tests per batch. } \\
\text { The number of sets of yield } \\
\text { tables to be produced. }\end{array}$ \\
\hline 2 & 1 & COMCU & $1-8$ & F8.3 & $\begin{array}{l}\text { Minimum cut in merchant- } \\
\text { able cubic feet to be included } \\
\text { in total yields. Must be at } \\
\text { least } 1.0 \text {. }\end{array}$ \\
\hline \multirow{3}{*}{3} & \multirow{3}{*}{$\begin{array}{c}1 \\
\text { per test }\end{array}$} & $\mathrm{COMBF}$ & $9-16$ & F8.3 & $\begin{array}{l}\text { Minimum cut in board feet } \\
\text { to be included in total yields. } \\
\text { Must be at least } 1.0 \text {. }\end{array}$ \\
\hline & & JCYCL & $1-4$ & I4 & $\begin{array}{l}\text { Interval between inter- } \\
\text { mediate cuts. A multiple } \\
\text { of RINT. }\end{array}$ \\
\hline & & MIX & $5-8$ & I4 & $\begin{array}{l}\text { Number of stocking levels } \\
\text { or values of DLEV to be } \\
\text { examined in one test. }\end{array}$ \\
\hline \multirow[t]{3}{*}{4} & \multirow[t]{3}{*}{$\begin{array}{c}1 \\
\text { per test }\end{array}$} & AGEO & $1-8$ & F8.3 & $\begin{array}{l}\text { Initial age to be shown in } \\
\text { a yield table. Stand age } \\
\text { when first thinning occurs. }\end{array}$ \\
\hline & & DBHO & $9-16$ & F8.3 & $\begin{array}{l}\text { Average stand d.b.h. just } \\
\text { prior to initial thinning at } \\
\text { stand age AGEO. }\end{array}$ \\
\hline & & DENO & $17-24$ & F8.3 & $\begin{array}{l}\text { Number of trees per acre } \\
\text { just prior to initial thinning } \\
\text { at stand age AGEO. }\end{array}$ \\
\hline
\end{tabular}


Card

type
Number of cards

RINT

$33-40$

SITE

$41-48$

THIN

49-56

START

$57-64$

5

1

per test

REGN(1) 1-8
Columns Format

F8.3

F8.3

F8.3

F8.3

F8.3

VLLV(1) 9-16

INVL(1) 17-24

REGN(2) 25-32

VLLV(2) $\quad 33-40$

$\operatorname{INVL}(2) \quad 41-48$

$\operatorname{REGN}(3) \quad 49-56$

\section{Description of variable}

Lowest growing stock level for intermediate cuts after initial thinning. Level will increase by 10 as many times as specified by MIX on card type 3 .

Number of years for which growth and infection equations make one projection of growth or change. Value is $\mathbf{1 0 . 0}$ for the equations given in appendix 1 .

Site index on which the set of yield tables is to be based. Growing stock level for initial thinning at age AGEO. May equal DLEV.

Stand age at which dwarf mistletoe infection begins. Never enter zero. Enter number larger than largest REGN(I) if infection will not occur during the rotation.

F8.3 Stand age at which first regeneration cut will occur. Must never be zero or blank, as this is rotation length for clearcutting.

F8.3 Percentage of previous DLEV to be left at age REGN(1). Will be zero with clearcutting. Enter as a decimal.

F8.3 New interval between cuts in effect after age REGN(1). Will be zero with clearcutting.

F8.3 Stand age at which second regeneration cut, if any, will occur. Removal of seed trees or second cut of shelterwood.

F8.3 Percentage of previous DLEV, including effect of VLLV(1), to be left at age REGN(2). May be zero. Enter as a decimal.

F8.3 New interval between cuts in effect after age REGN(2). May be zero.

F8.3 Stand age at which third regeneration cut, if any, will occur. Final cut of 3 -cut shelterwood. 
Subsequent operations are performed in the following order:

1. Computation of average height, basal area, volume, and mistletoe rating just prior to initial thinning.

2. Change of interval between cuttings and of residual stand density if a regeneration cut is due and if changes are needed. Entries on data card type 5 control the changes. If the stand is to be clearcut, stand age at time of clearcutting or REGN(1) is the only entry needed. Seed-tree cutting requires that values for all items to and including REGN(2) be punched in card type 5. REGN(1) is stand age at first regeneration cutting and REGN(2) is age of the seed trees when they are removed. The interval between these two cuttings is INVL(1). Up to three regeneration cuttings are possible with the shelterwood system. Stand age at final cut will be REGN(2) for two-cut shelterwood and REGN(3) for three-cut shelterwood. If a regeneration cut is scheduled, it will be made in the same steps as described below for thinnings.

3. Thinning and computation of the new mistletoe rating after thinning, if the currentrating is below 3.0. If thinning is possible, subroutines compute the new stand density and average d.b.h., as explained below. The main program then computes the new average stand height.

4. Computation of post-thinning volumes.

5. Computation of amounts removed by thinning and of values describing conditions before and after thinning.

6. Printing of before- and after-thinning values in the yield table.

7. Advancement of d.b.h., height, stand density, and mistletoe rating one prediction period and computation of new volumes. Mistletoe rating is computed as an increase from a previous value or as a projection from initial infection, depending upon whether or not thinning has occurred since infection.

8. Printing of values appropriate to the stand age, if thinning is not scheduled.

9. Rethinning, if thinning is scheduled, by return of program control to the operations described in item 2.
10. Repetition of operations described in items 2 to 9, inclusive, until stand age reaches the limit set by the largest value of REGN(I) on data card type 5.

Only one thinning in diseased stands will be from above, as simulated by SWCUT2. Subsequent thinnings in diseased stands will increase average d.b.h. and height, but by lesser amounts than in healthy stands where the smaller trees make up a larger percentage of those removed. This effect has been observed in subsequent thinnings of actual stands, and is simulated by SWCUT3.

Subroutines SWCUT1 and SWCUT3 compute average stand d.b.h. after thinnings that remove many of the smaller trees and thus increase average stand diameter and height. Successive percentages of trees to be retained (PRET) are tested until the relationship between d.b.h., basal area, and number of trees is mathematically correct and d.b.h. and basal area agree with the growing stock level specified by THIN or DLEV. Two major loops are provided in the subroutines because two equations are needed for estimating post-thinning d.b.h. (DBHE).

Subroutine SWCUT2 uses thinning standards based on, the goals of sanitation thinning, not on THIN or DLEV. The reduced infection rating to be attained (DMRT) is computed by the main program as a function of average stand d.b.h., as follows:

$\begin{array}{cc}\text { D.b.h. } & \\ \text { (Inches) } & \text { Rating } \\ 2 & 0 \\ 4 & 0.5 \\ 6 & 1.0 \\ 8 & 1.5 \\ 10 & 2.0\end{array}$

SWCUT2 then computes the reduction in stand density (REDT) needed to attain this goal, based on d.b.h. and rating just prior to thinning. D.b.h. after thinning (DBHT) can then be determined directly with the same equations as for DBHE in SWCUT1. Successive approximations are unnecessary because percentage of trees to be retained (PRET) is known before $\mathrm{DBHE}$ (as DBHT) is computed.

Replacement of several statements will modify the program for other utilization standards, species, or regions. Replacements needed are:

1. Statements for SQFT, DBHP, BREAK, BUST, and related computations that contain the ratio of DLEV or THIN to 80.0, if desired. This change is needed if standards for reserve stands in SWCUT1 and SWCUT3 will be different from those shown in the tabulation of the previous section. 
2. Statements from TOTO and TOTT, to make cubic volumes per acre correct for the species and tree volume equations selected.

3. Statements for FCTR and PRODinsubroutine SWVOL that are correct for the species, tree volume equations, and utilization standards selected.

4. Statements for HTSO, ADDHT, and PCT so that height growth, changes in height due to thinning, and reductions in growth caused by dwarf mistletoe will be appropriate for the species.

5. Statements for or that include DMR, DMRT, and REDT; to show correct relationship for the host-parasite interaction being simulated.

6. Statement for DBHO, based on a growth study in healthy stands of the species of interest, and a statement for TEM to compute the effect of mistletoe on diameter growth.

7. Statements for DBHE in subroutine SWCUT1 and SWCUT3 and for DBHT in SWCUT2 that apply to the species of interest.

8. Statements that describe periodic losses in numbers of trees in both healthy (OUT) and diseased (DIE) stands.

9. Table headings.

\section{A Sample Problem}

The following sample problem provides additional description of the data deck and of the output (appendix 2). It can also serve as a test problem to check accuracy of punching of the source deck and to test compatibility with local equipment.

Assume a forest composed of even-aged stands of ponderosa pine that differ in degree of infection by dwarf mistletoe. Problems to be solved by the manager of such a forest include:

1. What growth can be expected in healthy stands of known site quality for various combinations of thinning frequency and intensity?

2. How is this growth affected by various degrees of dwarf mistletoe infection and time of initial sanitation thinning?

3. On the basis of potential yields of each stand, is thinning, replacement, or no treatment appropriate for the stand at this time?

4. Does each treatment decision appear appropriate when impacts on other forest resources are considered?
Answers that contribute to good land management cannot be obtained unless all numerical results can be estimated to a useful degree of accuracy. Program SWYLD provides such estimates for trees and dwarf mistletoe. In the sample problem, yields of healthy stands are compared with those initially infected at age 10. Other variables remain constant for both tests except for stand conditions at initial thinning and intensity of thinning. No scheduled thinning will be performed if the dwarf mistletoe rating is 3.0 or greater. Regeneration will be by two-cut shelterwood with 20 years between removal and final cut. The data deck contains the following values:

NTSTS - 3, for healthy stands (test 1 ), diseased and thinned at age 30 (test 2), and diseased and first thinned at age 50 (test 3).

COMCU - 320.0 cubic feet, minimum commercial cubic-foot cut.

COMBF - 1500.0 board feet, minimum commercial board-foot cut.

JCYCL - 20 years.

MIX -3 , or 3 intensities of thinning will be examined in each test.

AGEO -30.0 years for two tests and 50.0 years for the third.

DBHO - 4.8 inches for two tests, 6.2 inches for the third.

DENO - 950.0 trees for two tests, 575.0 trees for the third.

DSTY - 80.0, lowest subsequent thinning level of the 3 to be examined.

RINT -10.0 years, prediction period of the equations.

SITE $\quad-70.0$ feet, base 100 years.

THIN -100.0 level for initial thinning.

START - 200.0, 10.0, and 10.0 years on type 3 data cards of test 1 , test 2 , and test 3, respectively. Any number larger than the largest value of REGN(I) could replace the 200.0 shown.

REGN(1) - 110.0 years, stand age at time of removal cut.

VLLV(1) - 50.0 percent, read as a decimal, amount of previous residual basal area to be left as shelterwood.

INVL(1) - 20 years, interval between removal and final cuts.

REGN(2) -130.0 years, stand age at time of final cut.

These values will provide data for comparison of the differences in yields between healthy and diseased stands, and between different types of diseased stands. Values must be read from data cards assembled in the order: 
(1) type 1, (2) type 2 , (3) type 3 of test 1 , (4) type 4 of test $1,(5)$ type 5 of test $1,(6)$ type 3 of test $2,(7)$ type 4 of test 2 , (8) type 5 of test $2,(9)$ type 3 of test $3,(10)$ type 4 of test 3 , and (11) type 5 of test 3 . Additional tests could be made to examine the effect of variations in thinning intensity or in any other control variable.

Tables produced by SWYLD can be used in many ways to assist in decisionmaking. For many purposes, yields of healthy stands will be desired so that long-range goals can be determined. Yields, numbers of noncommercial cuts, number of scheduled cuts that cannot be made, and size of the average tree are some of the values produced. Money yields and rates earned can be computed if necessary data on costs and stumpage values are available. Stand ages at culmination of mean annual increment, and rates earned can help the manager determine suitable rotations for his working groups.

A manager examining the tables in appendix 2 , for example, might reach the following conclusions:

1. A stand initially infested at age 10 and then left untreated for 40 years will produce very little merchantable volume by age 130 . The stand is already too heavily infested by age 50 for subsequent treatment to produce improvement.

2. A stand infested by dwarf mistletoe at age 10 but thinned at 20 -year intervals beginning at age 30 , can produce only a small volume of useful wood products. Yields, including thinnings, would be much less than those from healthy stands with the same site index and thinned according to the same schedule. Also, actual yields of diseased stands would be less than the computed volumes because no reduction has been made for amounts of wood lost due to pitch or distorted grain.

3. In healthy stands, largest yields would be produced with relatively light thinnings, such as to level 100. Comparing yields in thinned stands with and without dwarf mistletoe, diseased stands produce about a third of the merchantable cubic- and board-foot volumes of healthy stands.

\section{Literature Cited}

Andrews, S. R., and J. P. Daniels.

1960. A survey of dwarfmistletoes in Arizona and New Mexico. U. S. Dep.
Agr., Forest Serv., Rocky Mt. Forest and Range Exp. Stn., Stn. Pap. 49, 17 p. Fort Collins, Colo.

Hawksworth, F. G.

1961. Dwarfmistletoe of ponderosa pine in the Southwest. U. S. Dep. Agr. Tech. Bull. 1246, $112 \mathrm{p}$. and A. A. Lusher.

1956. Dwarfmistletoe survey and control on the Mescalero Apache Reservation,

New Mexico. J. Forest. 54: 384-390.

Korstian, C. F., and W. H. Long.

1922. The western yellow pine mistletoe: effects on growth and suggestions for control. U. S. Dep. Agr. Bull. 1112, $35 \mathrm{p}$.

Lightle, P. C.

1966. Dwarf mistletoe reduces basal area growth in ponderosa pine in the Southwest. (Abstr.) Phytopathology 56: 886-887.

Meyer, Walter H.

1938. Yield of even-aged stands of ponderosa pine. U. S. Dep. Agr. Tech. Bull. 630,59 p.

Myers, Clifford A.

1963. Volume, taper, and related tables for southwestern ponderosa pine. U. S. Forest Serv. Res. Pap. RM-2, 24 p. Rocky Mt. Forest and Range Exp. Stn., Fort Collins, Colo.

1971. Field and computer procedures for managed-stand yield tables. USDA Forest Serv. Res. Pap. RM-79, 24 p. Rocky Mt. Forest and Range Exp. Stn. Fort Collins, Colo.

, F.G. Hawksworth, and J.L. Stewart.

1971. Simulating yields in managed, dwarf mistletoe-infested lodgepole pine stands. USDA Forest Serv. Res. Pap. RM-72, 15 p. Rocky Mt. Forest and Range Exp. Stn., Fort Collins, Colo. , and Edward C. Martin.

1963. Mortality of southwestern ponderosa pine sawtimber after second partial harvest. J. Forest. 61: 128-130.

Pearson, G. A.

1938. Lighter cuts and larger yields in ponderosa pine. J. Forest. 36: 779-789.

1939. Mortality in cutover stands of ponderosa pine. J. Forest. 37: 383-387. Sperry, O. E.

1934. The rate of growth of the ponderosa pine in Estes Park, Colorado. Torrey Bot. Club Bull. 61: 19-34. 
PROGRAM SHYLO

D TAPUT, TAPE $=$ INPUT, TAPEG = DUTPUT

c TO CDMPUTE AND PRINT YIELO TABLES FOR EVEN-AGEO STANDS OF SOUTHWESTERN C PONDERDSA PINE WITH DR WITHDUT INFECTION BY OWARF MISTLETOE.

C OEFINITIONS OF VARIABLES.

ADDHT = INCREASE OR DECREASE IN AVERAGE STAND HEIGHT BY THINNING.

$A G E D=$ INITIAL AGE IN YIELD TABLE.

BASC $=$ BASAL AREA CUT PER ACRE.
BASO $=$ BASAL AREA PER ACRE BEFORE THINNING.

BAST = BASAL AREA PER ACRE AFTER THINNING.

BDFC $=$ BOARD FEET CUT PER ACRE.
$B D F O=$ BOARD FEET PER ACRE BEFDRE THINNING.

BDFO = BOARD FEET PER ACRE BEFORE THINNING.
BDFT $=$ BOARD FEET PER ACRE AFTER THINNING.

CFMC = MERCHANTABLE CU. FT. CUT PER ACRE.

CFMO = MERCH. CU. FT. PER ACRE BEFDRE THINNING.

CFMT = MERCH. CU. FT. PER ACRE AFTER THINNING.
COMBF = MINIMUM COMMERCIAL CUT, BOARO FEET.

COMBF = MINIMUM COMMERC IAL CUT, BOARO FEET

COMCU = MINIMUM CDMMERCIAL CUT, CU. FT.

OBHT = AVERAGE STAND D. B. H. BEFORE THINNING.

DENC = TREES CUT PER ACRE.

DEND = TREES PER ACRE BEFORE THINNING.

OENT = TREES PER ACRE AFTER THINNING.

OIE $=$ TREES LOST IN OISEASEO STANOS IN 10 YEARS, IN PERCENT.
DLEV $=$ GROWING STDCK LEVEL FOR INTERMEDIATE CUTS AFTFR THE FIRST. OMR = DWARF MISTLETOE INFECTION RATING

OMR = DWARF MISTLETOE INFECTION RATING.
DMRT = MAXIMUM INFECTION EXPECTED IN STANDS AFTER THINNING. GOAL

DSTY = LOR STANDS NOT ALREAOY BEYONO DMR OF 3.0 .

DSTY $=$ LOWEST VALUE OF DLEV USEO IN
HTSO = TREE HEIGHT BEFDRE THINNING.

HTSD $=$ TREE HEIGHT BEFDRE THINNING.
HTST $=$ TREE HEIGHT AFTER THINNING.

INVL (I) = NEW CUTTING CYCLE AFTER REGENERATION CUT I.

JCYCL = INTERVAL BETWEEN INTERMEDIATE CUTS.
JSBD = SUM OF BOARD FEET FROM ALL CUTS WITH YIELO OF COMBF OR

JSMC $=$ LARGER. SF MERCH. CU. FT. FROM ALL CUTS WITH YIELO OF COMCU

JSMC $=$ SUM OF

JSTF = SUM OF TOTAL CU. FT. FROM ALL CUTS.

KSTEP = INDICATOR WITH VALUE OF ONE IF CURRENT THINNING IS FRDM

BELOW ANO TWO IF CURRENT THINNING IS FRDM ABDVE.

INOICATOR WITH VALUE GREATER THAN ZERO IF A SCHEDULEO
THINNING HAS BEEN SKIPPEO BECAUSE MISTLETOE INDEX IS TOO HIGH THINNING HAS BEEN SKIPPEO BEC AUSE MISTLETOE INDEX
OR BECAUSE STAND IS ALREADY TO SPECIFIEO STDCKING.

MIX = NUMBER OF STOCKING LEVELS EXAMINED PER TEST. NFLAG = IND ICATOR WITH VALUE GREATER THE

NTSTS $=$ NBDV HAS BEEN MADE AT ANY TH.
NTER OFSTS PER BATCH.

OUT = PERCENT MORTALITY IN HEALTHY STANOS.

PCT = PERIODIC HEIGHT INCREASE IN INFESTED STAND, AS A PERCENTAGE

OF THE INCREASE IN COMPARABLE HEALTHY STANDS.

REOT = PERCENTAGE REOUCTION IN NUMBER OF TREES WHEN DMR IS

REOUCED TD DMRT BY THINNING.

REGN (I) = STAND AGE WHEN REGENERATION CUT I OCCURS.

RINT = NUMBER OF YEARS FDR WHICH A SINGLE PROJECTION IS MAOE.

ROTA $=$ FINAL AGE IN
SITE = SITE INDEX.

START = STANO AGE AT TIME OF INITIAL INFECTION

TEM = PERIODIC D.B.H. INCREASE IN INFESTED STAND, AS A PERCENTAGE

OF THE INCREASE IN COMPARABLE HEALTHY STANDS.

THIN = GROWING STOCK LEVEL FOR INITIAL THINNING

TOTC = TOTAL CUBIC FEET CUT PER ACRE.
TDTD = TOTAL CUBIC FEET PER ACRE BEFORE THINNING.

TOTT = TOTAL CUBIC FEET PER ACRE AFTER THINNING.

VLLVIII = PERCENT OF PREVIOUS OLEV TO BE LEFT AT REGN(I), ENTEREO

$$
\text { AS A OECIMAL. }
$$

COMMON BA, BAST, OBHO, OBHT, OENO, OMR, OMRT, FCTR, PRET, PRDO, REST, VDM OIMENSIDN VAR (11), TEMH(2), INVL (3), REGN (3), VLLV (3)

$1 \operatorname{VAR}(J)=1,11$

C REAO NUMBER OF TESTS PER bATCH FROM CARO TYPE ONE.

REAO $(5,5)$ NTSTS

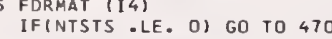

C REAO MINIMUM COMMERCIAL CUIS FOR CDMPUTATION OF COLUMN TOTALS FRDM
C CARO TYPE THO. C CARO TYPE TWO.

REAO $(5,10)$ COMCU, COMBF

VARIS) = COMBF

$\operatorname{VAR}(9)=$ COMBF
$\operatorname{VAR}(10)=$ COMCU

C EXECUTE PROGRAM ONCE FOR EACH SET OF INITIAL VALUES OF INTEREST.

OO $460 \quad 1=1$, NTSTS
JTEM $=0$

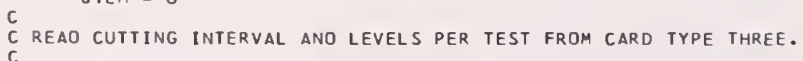

REAO 15,151 JCYCL, MIX

FORMAT 1214

IFI JCYCL .LE. O .OR. MIX.LE. O) GO TO 470
C READ INITIAL STAND VALUES FROM CARD TYPE FOUR.

READ $15,1 D)$ AGEO, OBHO, DEND, OSTY, RINT, SITE, THIN, START

$\operatorname{VAR}(1)=A G E O$

VAR $(2)=$ DBHO

$\operatorname{VAR}(3)=$ DENO
$\operatorname{VAR}(4)=$ DSTY

VAR $(4)=$ DSTY
$\operatorname{VAR}(5)=$ RINT
$\operatorname{VAR}(6)=$ SITE

VAR $(T)=$ THIN

$\operatorname{VAR}(B)=$ STAR

C READ SILVICULTURAL CDNTROLS FRDM CARD TYPE FIVE.

READ $(5,10) \operatorname{REGN}(1), \operatorname{VLLV}(1), \operatorname{INVL}(1), \operatorname{REGN}(2), \operatorname{VLLV}(2), \operatorname{INVL}(2), \operatorname{REGV}(3)$ $\operatorname{VAR}(11)=\operatorname{REGN}(1)$

DO $20 \mathrm{~L}=1,11$

IF (VARIL) . LE. O.D) GO TO 470

OLEY $=0.0$

\begin{tabular}{l} 
OLEV $=0 . D$ \\
$D O$ \\
\hline 5
\end{tabular}

$L=4-N A$

IFIREGN(L) .EQ. D.01 GO TO 35

ROTA = REGN(L)

35 CDNTINUE

C PROVIDE FOR SEVERAL GRDWING STDCK LEVELS PER TEST.

40 OO 460 M=1, MIX

$A=M$

$A D O H T=0.0$

$B D F O=0.0$
$B D F T=0.0$

CFMO $=0.0$
CFMT $=0.0$

$O M R=0.0$

$D M R T=0 . D$

$J S B D=0$

JSMC $=0$

JSTF $=0$

KSTEP $=1$

$K T R=0$

NFLAG $=0$
TIME $=0.0$

DLEV $=105 T Y+(A * 10.01)-10.0$
BASO $=$ DENO $* 0.0054542 *$ DBHO $*$ DBHO

C COMPUTE CURRENT OHARF MISTLETOE RATING, UNTHINNEO STANOS.

TIME = AGEO - START

IF (TIME. . LE. D.O O GO TO 45

OMR $=0.06533 *$ TIME $+0.03616 *$ SITE $-1.44 B 6$

IFIDMR $-L T$. D.0) DMR $=0.0$

C OBTAIN AVERAGe HEIGHT AND VOLUMES PER ACRE.

45 IFIAGED . GT 55.01 GO TO 50
HTSO $=0.01441$ * AGEO SITE - 0.12162 *AGED - 1.50953

SD HTSD $=0.59947-61.5019 / A G E O+0.80522$ *ALOGID(SITE) + 20.5252

IB * ALOGID(SITE) I AGEO

HTSD $=10.0$ \# HTSO

PCT $=1.073-0.0367 *$ DMR
IF $P$ PCT .GT. $1.0 i$ PCT $=1.0$
HTSO

c COMPUTE TOTAL CU. FT. AND CDNVERT TO OTHER UNITS.

$\mathrm{O} 2 \mathrm{H}=$ ОВНO $* \mathrm{OBHO} * \mathrm{HTSO}$

IF $(02 \mathrm{H}-G \mathrm{~T} .5000 .0)$ GO TO 60

TOTO $=(0.53313+0.00033 *$ BASO + $0.00179 * 02 \mathrm{H}) *$ DENO

60 TO TO 65 TOTO $=(0.00237 *$ BASO $+0.00211 * 02 \mathrm{H}-\mathrm{I} .09356) *$ OENO

IF IOBHO . LT. 5.0) GO TO 70

VOM $=$ OBHD
$B A=B A S O$

CALL SWVO

BOFO = TOTO $*$ PROO

TO REMO $=$ TOTO
RHIN

C ENTER LOOP FOR REMAINING COMPUTATIONS ANO PRINTOUT.

OO $355 \mathrm{~K}=1,100$

c CHANGe STANOARDS IF A REgENERATION CUT IS OUE.

90 IF(AGEO . GE. ROTA) GO TO 165

IF (AGEO . LT. REGNIII) GO TO 108

IF(AGEO .NE. REGN(1)) GO TO 95

OLEV $=$ OLEV * VLLV(1)

$J C Y C L=I N V L(1)$

GO TO 105

95 IFIAGEO - NE. REGN(2)) GO TO 100

OLEV $=$ OLEV * VLLV $(2)$ 
$J C Y C L=I N V L(2)$

100 IFIAGED. NE. REGN(3)) GO TD 10 DLEV $=$ OLEV * VLLV $(3$

REST $=$ OLEV
JYYCL $=$ INVL(3)

C INCREASE D.B.H. BY THINNING AND COMPUTE POST-THINNING VALUES.

105 IF(AGEO .EO. REGN(1) .DR. AGFO .EO. REGN(2)) GO TO 123

OOB IF(OMR. . LT. 3.0) GD TO 110

$B A S T=B A S O$
$O B H T=O B H O$

$O B H T=O B H O$
$O M R T=O M R$

HTST $=$ HTSO

$\begin{array}{ll}K T R & =1 \\ G O T O & 150\end{array}$

110 IF(DMR 0.0$)$ GO TO 120

IFIDMR. $E Q .0 .0)$
IFINFLAG.GT. O) GO TO 120
OMRT 115

OMRT $=0.25 * 0 B H O-0.50$

IF (OMRT . LT. O.O) OMRT $=0.0$
IF (OMRT . GE. DMR) GO TO 115

CALL SHCUT

NFLAG $=$

KSTEP $=$
GO TO 125

115 CALL SHCUT

KSTEP $=1$
OMRT $=$ OMR + $0.0279 *$ PRET -2.7

GO TO 125
125

CALL SWCUTI

KSTEP $=1$
GO TO 125

123 CALL SHCUTI

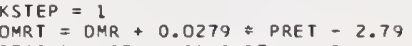

OMRT $=$ OMR $+0.0279 *$ PRET
IFIOMRT. . GT. 6.01 OMRT $=6.0$

25 IFIBAST. LT. BASDI GD TO 130

$B A S T=B A S O$
$O B H T=O B H O$

OMRT $=$ OMR

HTST $=$ HTSO

$\begin{array}{ll}K T R & =1 \\ G O & 10 \\ 150 & \end{array}$

C COMPUTE HEIGHT ANO VOLUMES AFTER THINNING.

130 GO TO $(135,140)$, KSTEP

130 GO TO $(135,140)$, KSTEP
135 AOOHT $=7.64 B 33-3$. B $22 B 6$ \# ALOG1OSPRET

GO TO 145

45 HTCUM $=$ HTCUM + AOOH

HTST = HTSO + ADOHT

5O JOENT = TBAST $/ 10.0054542 *$ OBHT *

BAST $=0.0054542$ OBHT \# OBHT \# OENT

$\mathrm{O} 2 \mathrm{H}=\mathrm{OBHT}$ ०OBHT * HTST

IF $102 \mathrm{H}=10.53313+0.00033 \neq \mathrm{BAST}+0.00179 * \mathrm{D} 2 \mathrm{H}) *$ OENT

GO TO 160 TO

c CONVERT total Cu. Ft. TO Other units.

160 IFIOBHT .LT. 5.01 GO TO 165

VOM $=O B H T$

$B A=B A S T$

BOFT = TOTT $\approx$ PROD

C CHANGE MOOE AND ROUNO OFF FOR PRINTING.

165 JAGEO $=\triangle A G E O$

JSITE = SITE

$\begin{aligned} \text { JOENO } & =\text { OENO }+0.5 \\ \text { JHTSD } & =\text { HTSO }+0.5\end{aligned}$

JOTO $=1$ TTOTO $* 0.11+0.5$

JTOTO $=$ JTOTO $* 10$

JCFMO $=$ ICFMO $* 0.511+0.5$

$\begin{aligned} \text { JCFMO } & =\text { JCFMO } * 10 \\ \text { JBOFO } & =\text { (BOFO } * 0.01)+0.5\end{aligned}$

JBOFO $=$ IBOFO $\div 0.011$
JBOFO $=$ JBDFO $\$ 100$

JBOFO $=$ JBDFO $* 100$

JHTST $=$ HTST +0.5
JTOTT $=($ TOTT $* 0.1)+0.5$

JTOTT $=$ JTDTT $* 10$
JCFMT $=$ (CFMT $* 0.1)+0.5$

JCFMT $=$ JCFMT $* 10+0.5$

IF ( JCFMT . GT. JCFMO) JCFMO = JCFMT

JBOFT $=(B O F T * 0.01)+0.5$

IF ( JBOFT . GT. JBOED) JBOED = JBOFT

$J B A S T=B A S T+0.5$

JDENC $=$ JOENO - JDENT

JBASC $=$ JBASO - JBAS

JTOTC = JTOTO - JTOT

IFI JCFMC . LE. O) JCFMC $=0$

JBOFC $=$ JBOFO - JBOFT
IFI JBOFC . LE. O) JBOFC $=0$

C SUM PERIOOIC CUTS FOR LAST LINE OF YIELO TABLE.

IF(AGEO .GE. ROTA) GO TO 190

JSTF = JSTF + JTOTC

CFMC = JCFMC

IF(CFMC . LT. COMCU) GO TO 170

$\begin{aligned} \text { JSMC } & =\text { JSMC }+ \text { JCFMC } \\ 170 \mathrm{BOFC} & =\text { JBOFC }\end{aligned}$

IFIBOFC $D$ LT. COMBFI 60 TO 190

C HRITE HEADINGS FOR YIELO TABLE.

I90 IFIK .GE. 2) GO TO 220

WRITE $(6,195)$ JSITE. THIN, OLEV

195 FORMAT $(1 \mathrm{H} 1, / / /, 39 \mathrm{x}, 53 \mathrm{HY}$ IEL OS PER ACRE OF EVEN-AGFI STANOS DF PON IEROSA PINE/1H, 57X, 1 I HSITE INOEX, $13 / 1 \mathrm{H}, 38 \mathrm{~B}, 29 \mathrm{HTH}$ INNING INTENSITY 2- INITIAL- ,F5.0,2 2,12 HSUBSEQUENT- ,F5.

200 FORMAT 1 , 1 HO, $25 x, 3$ BHENTIRE STANO BEFORE AND AFTER THINNING, $28 X, 26$ HP IERIDOIC INTERMEOIATE CUTS,

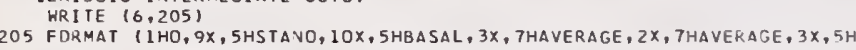

1TOTAL, $3 x$, 9HMERCHANT,$- 3 x$, 9 HSAHTI MBER, 9x, 5 HBASAL, $4 x$, 5 HTOTAL, 3X, 9HMER
WRITE $(6,210)$

FORYAT (1H, $10 x$, 3HAGE, $4 x, 5$ HTREES, $3 x$, 4HAREA, 4X, 6HD. B. H., $3 x, 6$ HHE 1 GHT 2. 6 HVOLUME, $2 X, 11$ HABLE VOLUME, $4 x, 6$ HVOLUME

1, 6HCUT $11 \mathrm{H}, \mathrm{BX}, 7 \mathrm{H}$ (YEARS), 3X, 3HNO., 3X, 6HSU. FT. $4 X$, 3HI V., 6X, 3HFT. $4 X$

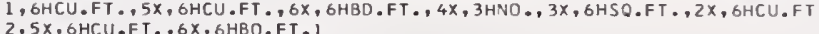

C WRITE TABLE ENTRIES DF OIAMETER, VDlumes, etc.

220 WRITE $(6,225)$ JAGEO, JOENO, JBASO, OBHD, JHTSO, JTOTO, JCFMO, JEOFO FORMAT $(1 \mathrm{HO}, 9 \mathrm{x}, 14,4 \mathrm{x}, 15,2 \mathrm{x}, 14,5 \mathrm{x}, \mathrm{F5}, 1,5 \mathrm{x}, 13,4 \mathrm{x}, 15,6 \mathrm{x}, 15,6 \mathrm{x}, 16)$ IF(AGEO . GE. ROTA) GO TO 370 . WRI TE $(6,230)$ JAGEO, JOENT, JBAST, OBHT, JHTST, JTOTT, JCFMT, JLOFT, JDE SC 1,JBASC, JTDTC, JCFMC, JBDFC

230 FORMAT 11H, $9 x, 14,4 x, 15,2 x, 14,5 x, F 5,1,5 x, 13,4 x, 15,6 x, 15,6 x, 16,4 x, 1$

C compute values for each perioo. thin as specified.

IRINT = RINT
IK $=$ JCYCL I IRINT

$O D 345 \mathrm{~L}=1,1 \mathrm{~K}$
$A G E O=A G E D+R I N T$

IF(AGEO.GT. ROTA) GO TO 370

C COMPUTE CURRENt OHARF Mistletoe rating.

TIME = AGEO - START
IFIOMR. .GT. O.0) GO TO 250

IFITIME.

OMR $=0.06533 \div$ TIME $+0.03616 \div$ SITE -1.4486

GO TO 260

IFIOMRT. LE. 1.01 GO TO 255

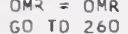

255 OMR $=$ OMRT $+10.03+0.03 B *$ OMRII $*$ RINT

IFIL. LE. 2) 60 TO 260

260 IFIOMR. LT. 0.01 OMR $=0.0$

IF OMR . LT. O.0 OMR $=0.0$

C COMPUTE NEW O.B.H. Before THINNING AVO ROUNO OFF TD 0.1 INCH.

265 OBHO $=1.0097 *$ OBHT $+0.0096 *$ SITE- $(1.5766 * A L O G 10(E A S T))+3.3021$ IFTOMRT . LE. 3.5) 60 TO 270

- $0.056 *$ OMRT -0.1971

$270 \mathrm{IOBHO}=\mathrm{OB} 1+0 \neq 10.0+0.5$

OBHO $=$ IORHO
OBHO $=$ OBHO $* 0$.

OIE $=0.0$

IFIOMRI 1 T 1.01 GO 10.273

OIE $=20.66469+4.42271$

IFE $=$ OIE $* 0.01$
IFIOIE.LT* O.01 DIE $=0.0$

373 OUT $=0.0$.

IFIOBHT.GE. 10.01 GO TO 275

DUT $=0.00247+0.00124 * \mathrm{OBHT}^{2}+0.0002 \mathrm{~B} * \mathrm{OBHT} * 0 \mathrm{OHT}+0.0000052$

IFIOUT . LT 0.01 OUT $=0.0$

5 IFIOIE. LT. OUTI DIE = DUT

JOENO $=$ IOENT $*(1.0-$ OIE $))+0.5$

DENO = JOENO

C OBTAIN AVERAge height and VOLUMES PER ACRE.

$00300 \mathrm{~J}=1.2$

LUB TO $(2 B O, 2 B 5)$, LUB

$2 B O$ YARS $=$ AGEO

60 TO 290

$2 B 5$ YARS $=\triangle A G E O-R I N T$

IFIYARS.GT. 55.0) GO TO 205

TEMH (J) $=0.01441$ * YARS \# SITE - 0.12162 * YARS - 1.50953

295 TEMH $300=0.59947-61.5019$, YARS + $0.80522 * A L D G 10(S I T E)+20.5$ 12528 * ALOGIO(SITE) Y YARS

300 CONTINUE

PCT $=1.0-0.0002 \neq$ OMRT $=$ DMRT $*$ DMRT

CHNG $=$ ITEMH(i) - TEMH(2) $) \neq P C T$

C COMPUTE total CU. FT. ANO CONVERT to other units.

ООН $=$ ОВНО $\approx \mathrm{OBHO} \approx \mathrm{HTSO}$

IF $102 \mathrm{H}$. GI $5000.01-\mathrm{GO}$ TO 305

作 $10.53313+0.00033 *$ BASO $+0.00179 *$ O2H $) *$ OEVO

305 TOTO $=10.00237 *$ BASO $+0.00211 * 02 \mathrm{H}-1.093561 \neq$ OENO

310 IFIOBHO. LT. 5.01 GO TO 315

$V O M=O B H O$
$B A=B A S D$

$B A=B A S D$

BOFO $=$ TOTO * PROO
CEMO

C TEst if Regeneration CUt is OUE.

315 on $320 \mathrm{KU}=1,3$

320 IFIAGED . EQ. REGN(KUI) GO TO 90

C CHANGE MOOE ANO ROUNO OFF FOR PRINTING.

IF(L. EO. IK) GO TO 350

KOENO $=$ OENO
KAGEO $=$ AGEO

KHTSO $=$ HTSO + 0.

KBASD $=$ BASO +0.5

KTOTO $=($ TOTO $* 0.1)+0.5$

KCFMO = ICFMO $* 0.11+0.5$

KCFMO $=$ KCFMD $* 10$

KBDFO $=(B O F O \div 0.011)+0.5$

KBOFO $=$ KBOFO $\neq 100$

C hrite VAlues fDR tHE PERIOO IF THINNING IS NOT DUE.

WRITE $(6,225)$ KAGEO, KDENO, KBASO, OBHO, KHT SD, KTOTO, KCFMO, KBOFO

OBHT $=$ OBHO

BAST $=$ BASO
DENT $=$ OEND

DMRT $=$ OMR 
HTST $=$ HTSO
345 CONTINUE

C PREPARE TO START LDOP AGAIN FOR NEXT THINNING.

350 REST $=$ DLEV

C ADD FINAL CUTS TO TOTAL YIELOS ANO HRITE TOTAL YIELOS.

370 JSTF = JSTF + JTOTO

CFMD $=$ JCFMO
IFICFMD . LT. COMCU) 60 TO 375

JSMC $=$ JSMC + JCFMO

375 BOFO = JBDFO

IF (BDFO . LT - COMBF) GD TO $3 B D$
JSBD $=$ JSBO + JBOFO

3BD WRITE $(6,3 B 5)$, JSTF, JSMC, JSBD

3 B5 FORMAT (1HD, $1,67 X, 12$ HTOTAL YIELDS, 20X, 14,6X, $14,8 X, 15$ )

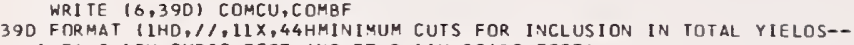
,F6. O, 15 H CUBIC FEET ANO,F $7 . D, 11 \mathrm{H}$ BOARO FEET

IF(START. GE. ROTA) GO TO 405

400 FORMAT I IHD, IDX, 41 HDHARF MISTLETDE INFECTIDN STARTED AT AGE, F4, 0, $16 H$ AND RATING WAS, F5.1,BH AT AGE,F4.0)

GO TO 415
HRITE $(6,410)$ ROTA

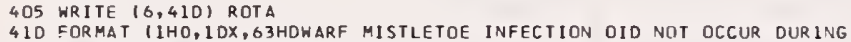

410 IIHE ROTATION OF FHA MISTLETOE

1 THE ROTATION OF, F $4.0,7 H$
415 IFIXTR.EO. DI GO TO 425

WRI TE $(6,420)$

420 FORMAT $(1$ HOD, LOX,52HNOTE THAT NOT ALL SCHEOULEO THINNINGS HERE POSS 425 HRITE 16,430$)$

425 HRITE 16,430$)$ FORMAT (IHD, $40 X, 6$ BHMERCH. CU. FT. - TREES 6.0 INCHES O.B.H. ANO LA

IRGER TO $4.0-1$ NCH TOP.)
WRITE $(6,435$ )

435 FORMAT IIHD, IOX,6BHBD; FT. - TREES 10.0 INCHES D.B.H. ANO LARGER T
IO VARIABLE TOP LIMIT.;

c PREPARE FDR NEXT TABLE OF THE TEST.

$A G E O=V A R(1)$
$O B H D=V A R(2)$

OBHO $=$ VENO $=$ VAR (3)
JCYCL

SOD CONTINUE

C PROgRAM CDNTROL goes here IF ANY Unhanted zerds IN DATA OECK.

470 WRITE 16,4 BD)

4BD FORMAT 11HI,///,10X,64HEXECUTIDN STDPPEO BECAUSE OF NEGATIVE OR ZE 500 CALL EXIT

SUBRDUTINE SHVOL

C TO CONVERT tOTAL CU. FT. TO MERCh. CU. FT. ANO tO BO. FT.

COMMON BA, BAST, OBHO, OBHT, OENO, DMR, OMRT, FCTR, PRET, PROD, REST, VOM

$F C T R=0 . D$

PRDD $=$ D.D

C OBTAIN CONVERSION FACTORS FOR MERCH. CU. FT. - VOLUMES TO 4.0-INCH TOP C IN TREES 6.0 INCHES D.B.H. AND LARGER.

IFIVDM .GT. 6.5) GO TO

FCTR $=D .25222 *$ VOM -1.01119

2 IFIVOM.GT, 10.01 G 0.104

FCTR $=3.02485-0.09957 *$ VDM $-11.35814 / \mathrm{VDM}$

GO TO 6

4 FCTR $=1.03936-1.41034, \mathrm{VOH}$

C OBTAIN CONVERSION FACTDRS FDR BO. FT. - VDLUMES TO VARIABLE TOP IN C OBTAIN CONVERSION FACTDRS FDR BO. FT.
C TREES 10.0 INCHES D.B.H. AND LARGER.

IFIVDM.GT. 11.5$)$ GO TD B

$P R D D=D . D D 2 B * B A+D .04355 * V D M * V O M-2.7 B 326$

$B P R O O=0.83943+0.20531 *$ VOM

10 RETURN

SUBROUTINE SWCUTI

C TD ESTIMATE INCREASE IN AVERAGE D. G.H. DUE TO THINNING SOUTHIHESTEKN C PONDEROSA PINE IF DHARF MISTLETOE RATING EOUALS ZERO.

COMMDN BA, BAST, DBHO, OBHT, DENO, OMR, DMRT, FCTR, PRET, PROD, KEST, VON IF(DBHO .LT. 9.5) GO TO 30

C COMPUTE D.B.H. IF DBHO IS LARGE ENDUGH FOR BASAL AREA TO REMAIV CONSTANT.

PRET $=100.0$

DD $21 K J=1,100$

TFIPRET. LT $50 . D)$ GO TO 5
OBHE $=0.73365 * 1.0200 B * 0 B H D-0.01107 *($ PRET -50.0$)-0.0001$

$14 *$ (PRET $-5 D . D) *($ PRET -50.0$)$
POB TO 11

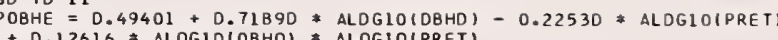

POBHE $=0.49401$ t D.7LB

11 IOBHE $=$ OBHE *

$\mathrm{OBHE}=\mathrm{IDBHE}$

OBHE $=$ D

OENE

NDENE $=$ OENE + D.

BASE $=$ NDENE

NBASE = BASE* $1 D * D+D, 5$

$B A S E=N B A S$

$B A S E=B A S E * D$.

TMPY $=0$. DD54542* OBHE $*$ OBHE

TEM = BASE - REST

IF (TEM

IFITEM .LT 4.01 GD TO 20

GO TO 21

20 PRET = PRET - 0.3

21 CONTINUE

C COMPUTE O.B.H. IF BASAL AREA INCREASES WITH O.B.H.

30 PRET $=40.0$

IF(DBHO .GT. 7.D) PRET $=70.0$

DO $65 \mathrm{~J}=1,100$
IF(PRET . GE. 50.0$)$ GO TO 40

PDBHE $=0.49401+0.71890 * A L O G 1 D(0 B H O)-0.22530$ AL OGLIOSPRET

$1+0.12616$ * ALOGIDIOBHO) \# ALOGID(PRET)

$\mathrm{OBHE}=10.0 *$ POBHE

GO TO 45
40 DHE $=0.73365+1.02008 * 08 H D-0.01107 *(P R E T-50.0)=0.0001$

$14 *$ (PRET - 50.D) * PRET - 50.0)

5 IDBHE = OBHE * ID D + D

$\mathrm{OBHE}=\mathrm{TOBHE}$

$D B H E=D B H E * 0.1$

$\$ 0.011$

NDENE = OENE + 0.5

DASE =

NBASE $=$ BASE $* 10.0+0.5$

$B A S E=N B A S E$

BASE $=$ BASE $* 0.1$

BREAK $=49.9 \%$ REST $B$ BD. D

$O B H P=(B 0.0 / R E S T) *(D .0 B 6 B 2 * B A S E)+0.94636$

GO TD 52

SD BUST $=66.2$ (REST $/ B 0.0$

IF (BASE .GT. BUST) GO TO 51
OBHP $=(B 0.0$, REST $) * 10.10938 *$ BASE $)-0.17 B 5 B$

GO TO 52

BASE * $\{B D . D /$ REST

TEM $=$ TMPY * TMPY TMPY $-0.26673 *$ TEM + $0.0012539 *$ TEM * TMPY

$1-448.76 B 33$

TMPY .GT. BD, O) DBHP $=08 \mathrm{OBO}+0.8$

DBHP $=1084 P$

$D$ DHP $=$ DBHP $\#$ D.1

IF (DBHP - DBHE) $60,70,6$

D PRET = PRET * 1.02

GO TO 65

65 CONTINUE

$c$
$c$

CDMPUte POST-THINNing basal aREA.

IFIOBHT.GT. 5.01 GO TO 75
SOFT $=11.58495 * 08 T^{-}-11.09724$

GO TO 76

5 GO TO 76
IFIDBHT.GE. 10.01 GO TO 77
TEM $=$ DBHT DBHT

SOFT $=7.76226$ \%OBHT +D.B5289* TEM -0.07952 * TEN * DBHT-3.45624

76 BAST $=$ (REST, BO.D) \# SOFT

77 BAST = REST

BO RETURN
ENO

c TO ESTIMATE INCREASE IN AVERAGE D.B.H. OUE TO THINNING SOUTHWESTERN C PONDEROSA PINE IF OHARF MISTLETOE RATING DETERMINES THE STANDARDS. COMMON BA, BAST, OBHO, OQHT, DENO, OMR, OMRT, FC TR, PRET, PROO, REST, VOM

C CDMPute stand density after a thinning that reouces the index,

IFIOMR .LT. 2.D) GO TO 5

KEOT $=77.5-8.5 *$ DBHO + $10.0 *$ DMR

GO TO 10

5 REOT $=15.5-B .5 * 08 H O+41.0 *$ DMR

DENT =

IOENT $=$ DENT +0.5

OENT = IDENT

C COMPUTE D.B.H. AFter thinning tO OESIREO DENSITY.

IFIPRET .LT. 50.01 GO TO 15 $1-50.0)$ * (PRET -50.0$)-0.91172$

GO TO 20 * 5 ( 5 D

15 DBHT $=$ D.5161B * ALOGID(PRET) +1.692
1 ALOGIO(PRET) *ALOG1O(DBHO) 1.03421

$2010 B H T=D B H T * 10.0+0.5$

$\mathrm{DBHT}=\mathrm{IDBHT}$

DBHT $=$ DBHT $* 0.1$
BAST $=$ D.DD54542*OBHT*DBHT*DENT

RETURN 
SUBROUTINE SWCUT3

C TO ESTIMATE INCREASE IN AVERAGE O.8.H. OUE TO THINYING FROM BELOW IF C OWARF MISTLETOE RATING IS GREATER THAN ZERO.

COMMON BA, BAST, OBHO, OBHT, OENO, OMR, OMRT, FCTR, PRET, PROO, REST, VOM

C COMPUTE 0.8.H. IF OBHO IS LARGE ENOUGH FOR BASAL AREA TO REMAIN CONSTAVT.

PRFT $=100.0$
00 LI KJ=I,100

OO 21 KJ $=1,100$
IFIPRET. LT. 50.01 GO TO 5

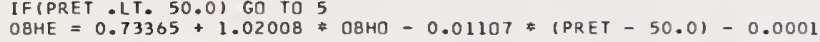
$14 *($ PRET -50.0$) \div($ PRET -50.0$)$

GO TO 11

POBHE $=0.49401+0.71890 *$ ALOG1O(OBHO) $-0.22530 *$ ALOGID(PRET)

+0.12616 * ALOG1O(OBHO) * ALOGIO(PRET)

OBHE $=10.0 \%$ POBHE

OBHE $=08 \mathrm{OBO}+\mathrm{TEM} * 0.5$
$\mathrm{IOBHE}=0 \mathrm{OBHE}+10.0+0.5$

OBHE $=$ IOBHE

OBHE $=$ OBHE $* 0.1$
OENE $=$ OEND $*$ PRET $\neq 0.01$

OENE = OENO

BASE $=0.0054542 * 0 B H E *$ OBHE $*$ OENE

NBASE $=8$ ASE $\neq 10.0+0.5$

$8 A S E=N B A S E$

BASE $=$ BASE $\approx 0.1$
TMPY $=0.0054542 * 08 \mathrm{HE} * 08 \mathrm{HE}$

$T E M=B A S E-R E S T$

IF (TEM.LE. TMPY) GO TO 70

IFITEM LT: 4.0 ) GO TO 20

PRET $=$ PRET -1.0

20 PRET = PRET - 0.3

21 CONTINUE
GO TO 70

C COMPUTE U.8.H. IF BASAL AREA INCREASES WITH O.B.H.

30 PRET $=40.0$

IF(OBHO .GT. 7.0) PRET $=70.0$

$0065 \mathrm{~J}=1,100$

IFIPKET. GE. 50.0) GO TO 40

POBHE $=0.49401+0.71890 *$ ALOG1O(O8HO $)-0.2253 C$ ALOGIOIPRET

$1+0.12616 *$ ALOG $10(08 H O) \neq A L O G 10(P R E T)$
OBHE $=10.0 \neq$ POBHE
GO 1045

40 DBHE $=0.73365+1.0200 B * 08 H 0-0.01107 *$ PRET $-50.01-0.0001$

$14 *($ PRET -50.0$) *($ PRET -50.0$)$

DBHE $=08 H O+T E M+0.5$

$\mathrm{IOBHE}=\mathrm{OBHE} * 10.0+0.5$

OBHE $=1$ TOBHE

OENE $=$ OENO 0.1 PRET $\div 0.011$

NOENE $=$ DENE + 0.5

OENE = NOENE

BASE $=0.0054542 *$ OBHE $*$ OBHE $*$ OENE

NBASE $=$ BASE
BASE $=$ NAASE

BASE $=$ NBASE
BASE $=$ BASE 0.

BREAK $=49.9$ * REST $/ 8000$

IFIBASE. GT. BREAK $)$ GO TO 50
OBHP $=180.0$, REST $) \neq 10.086 B 2 * B A S E)+0.94636$

50 BUST $=66.2 *$ (REST 180.01

OBHP $=(80.0$, REST) * $(0.10938$ * BASE $)-0.1785$

GO TO 52

1 THPY $=$ BASE $* 180.0 /$ REST

IEM $=$ TMPY *TMPY TMPY $-0.26673 *$ TEM $+0.0012539 *$ TEM * TMPY

IFITMPY.GT. 80.01 OBHP $=08$ DBO + 0.8

$25 \mathrm{IOBHP}=$ OBHP

OBHP $=108 \mathrm{H}=08 \mathrm{HP} * 0.1$
OBH

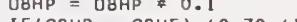

IF( OBHP - OBHE) $60,70,61$
PRET $=$ PRET $\approx 1,02$

GO $\mathrm{TO} 65$

1 PRET $=$ PRET * 0.98

65 CONIINUE

C COMPUTE POST-THINNING BASAL AREA.

IFIOBHT. .GT. 5.01 GO TO 75

SOFT $=11.58495 * 08 \mathrm{OH}-11.0972$

25 IFI TO 76 . GE. 10.01 GO TO 77

$\begin{aligned} 6 \text { SAFT } & =7.76226 * 08 \mathrm{HT}+0.85289 \\ 6 \text { BAST } & =(\text { REST } / 80.0) * 50 \mathrm{FT}\end{aligned}$

GO TO BO

77 BAST = REST
BO RETURN

ENO 


\section{APPENDIX 2 \\ Output of Sample Problem}

YIELDS PER ACRE DF EVEN-AGED STANDS DF PDNDERDSA PINE

THINNING INTENSITY- INITIAL- 100. SUBSEQUENT- 80.

ENTIRE STAND BEFDRE AND AFTER THINNING

PERIDDIC INTERMEDIATE CUTS

\begin{tabular}{|c|c|c|c|c|c|c|c|c|c|c|c|c|}
\hline $\begin{array}{l}\text { STAND } \\
\text { AGE } \\
\text { (YEARS) }\end{array}$ & $\begin{array}{l}\text { TREES } \\
\text { ND. }\end{array}$ & $\begin{array}{l}\text { 8ASAL } \\
\text { AREA } \\
\text { SQ.FT. }\end{array}$ & $\begin{array}{c}\text { AVERAGE } \\
\text { D.8.H. } \\
\text { IN. }\end{array}$ & $\begin{array}{c}\text { AVERAGE } \\
\text { HEIGHT } \\
\text { FT. }\end{array}$ & $\begin{array}{l}\text { TDTAL } \\
\text { VDLUME } \\
\text { CU.FT. }\end{array}$ & $\begin{array}{c}\text { MERCHANT- } \\
\text { ABLE VDLUME } \\
\text { CU.FT. }\end{array}$ & $\begin{array}{l}\text { SAWT IMBER } \\
\text { VDLUME } \\
\text { 8D.FT. }\end{array}$ & $\begin{array}{c}\text { TREES } \\
\text { ND. }\end{array}$ & $\begin{array}{l}\text { 8ASAL } \\
\text { AREA } \\
\text { SQ.FT. }\end{array}$ & $\begin{array}{l}\text { TDTAL } \\
\text { VDLUME } \\
\text { CU.FT. }\end{array}$ & $\begin{array}{c}\text { MERCHANT- } \\
\text { ABLE VDLUME } \\
\text { CU.FT. }\end{array}$ & $\begin{array}{l}\text { SAHTIMBER } \\
\text { VDLUME } \\
\text { 8D.FT. }\end{array}$ \\
\hline 30 & 950 & 119 & 4.8 & 25 & 1530 & 360 & 0 & & & & & \\
\hline 30 & 373 & 68 & 5.8 & 27 & 810 & 360 & 0 & 577 & 51 & 720 & 0 & 0 \\
\hline 40 & 370 & 96 & 6.9 & 36 & 1330 & 920 & 0 & & & & & \\
\hline 50 & 365 & 121 & 7.8 & 44 & 1970 & 1560 & 800 & & & & & \\
\hline 50 & 188 & 76 & 8.6 & 45 & 1230 & 1040 & 800 & 177 & 45 & 740 & 520 & 0 \\
\hline 60 & 187 & 96 & 9.7 & 52 & 1730 & 1530 & 2700 & & & & & \\
\hline 70 & 186 & 114 & 10.6 & 58 & 2420 & 2190 & 5900 & & & & & \\
\hline 70 & 113 & 80 & 11.4 & 59 & 1730 & 1580 & 5400 & 73 & 34 & 690 & 610 & 500 \\
\hline 80 & 113 & 96 & 12.5 & 65 & 2320 & 2150 & 7900 & & & & & \\
\hline 90 & 113 & 112 & 13.5 & 70 & 2930 & 2740 & 10600 & & & & & \\
\hline 90 & 72 & 80 & 14.3 & 70 & 2120 & 2000 & 8000 & 41 & 32 & 810 & 740 & 2600 \\
\hline 100 & 72 & 93 & 15.4 & 75 & 2620 & 2490 & 10500 & & & & & \\
\hline 110 & 72 & 106 & 16.4 & 78 & 3130 & 2990 & 13200 & & & & & \\
\hline 110 & 22 & 39 & 18.1 & 80 & 1190 & 1150 & 5400 & 50 & 67 & 1940 & 1840 & 7800 \\
\hline 120 & 22 & 47 & 19.7 & 83 & 1480 & 1430 & 7200 & & & & & \\
\hline 130 & 22 & 54 & 21.2 & 86 & 1770 & 1720 & 9200 & & & & & \\
\hline \multicolumn{10}{|c|}{ TDTAL YIELDS } & 6670 & 5430 & 19600 \\
\hline
\end{tabular}

MINIMUM CUTS FDR INCLUSIDN IN TDTAL YIELDS-- 320. CU8IC FEET AND 1500. 8DARD FEET

DWARF MISTLETOE INFECTIDN DID NDT DCCUR DURING THE RDTATIDN DF 130. YEARS.

MERCH. CU. FT. - TREES 6.0 INCHES D.8.H. AND LARGER TD 4.0-INCH TDP.

8D. FT. - TREES 10.0 INCHES D.8.H. AND LARGER ID VARIA8LE TDP LIMIT.

YIELDS PER ACRE DF EVEN-AGED STANDS DF PDNDERDSA PINE

SITE INDEX 70
THINNING INTENSITY- INITIAL- 100 . SUBSEQUENT- 90.

ENTIRE STAND BEFDRE AND AFTER THINNING

PERIDDIC INTERMEDIATE CUTS

\begin{tabular}{|c|c|c|c|c|c|c|c|c|c|c|c|c|}
\hline $\begin{array}{l}\text { STAND } \\
\text { AGE } \\
\text { (YEARS) }\end{array}$ & $\begin{array}{c}\text { TREES } \\
\text { ND. }\end{array}$ & $\begin{array}{l}\text { 8ASAL } \\
\text { AREA } \\
\text { SQ.FT. }\end{array}$ & $\begin{array}{c}\text { AVERAGE } \\
\text { D.8.H. } \\
\text { IN. }\end{array}$ & $\begin{array}{l}\text { AVERAGE } \\
\text { HEIGHT } \\
\text { FT. }\end{array}$ & $\begin{array}{l}\text { TDTAL } \\
\text { VDLUME } \\
\text { CU.FT. }\end{array}$ & $\begin{array}{c}\text { MERCHANT- } \\
\text { ABLE VDLUME } \\
\text { CU.FT. }\end{array}$ & $\begin{array}{l}\text { SAWT IMBER } \\
\text { VDLUME } \\
\text { 8D.FT. }\end{array}$ & $\begin{array}{c}\text { TREES } \\
\text { ND. }\end{array}$ & $\begin{array}{l}\text { 8ASAL } \\
\text { AREA } \\
\text { SQ.FT. }\end{array}$ & $\begin{array}{l}\text { TDTAL } \\
\text { VOLUME } \\
\text { CU.FT. }\end{array}$ & $\begin{array}{c}\text { MERCHANT- } \\
\text { A8LE VDLUME } \\
\text { CU.FT. }\end{array}$ & $\begin{array}{l}\text { SAWT IMBE } \\
\text { VDLUME } \\
\text { 8D.FT. }\end{array}$ \\
\hline 30 & 950 & 119 & 4.8 & 25 & 1530 & 360 & 0 & & & & & \\
\hline 30 & 373 & 68 & 5.8 & 27 & 810 & 360 & 0 & 577 & 51 & 720 & 0 & 0 \\
\hline 40 & 370 & 96 & 6.9 & 36 & 1330 & 920 & 0 & & & & & \\
\hline 50 & 365 & 121 & 7.8 & 44 & 1970 & 1560 & 900 & & & & & \\
\hline 50 & 211 & 85 & 8.6 & 45 & 1380 & 1170 & 900 & 154 & 36 & 590 & 390 & 0 \\
\hline 60 & 210 & 106 & 9.6 & 52 & 1910 & 1690 & 2900 & & & & & \\
\hline 70 & 209 & 126 & 10.5 & 58 & 2670 & 2420 & 6300 & & & & & \\
\hline 70 & 129 & 90 & 11.3 & 59 & 1940 & 1780 & 5900 & 80 & 36 & 730 & 640 & 400 \\
\hline 80 & 129 & 106 & $12 \cdot 3$ & 65 & 2560 & 2370 & 8600 & & & & & \\
\hline 90 & 129 & 123 & 13.2 & 70 & 3200 & 2990 & 11400 & & & & & \\
\hline 90 & 84 & 90 & 14.0 & 70 & 2370 & 2230 & 8800 & 45 & 33 & 830 & 760 & 2600 \\
\hline 100 & 84 & 103 & 15.0 & 75 & 2900 & 2740 & 11400 & & & & & \\
\hline 110 & 84 & 116 & 15.9 & 78 & 3430 & 3260 & 14100 & & & & & \\
\hline 110 & 27 & 46 & 17.6 & 80 & 1390 & 1330 & 6200 & 57 & 70 & 2040 & 1930 & 7900 \\
\hline 120 & 27 & 54 & 19.1 & 83 & 1700 & 1640 & 8100 & & & & & \\
\hline 130 & 27 & 62 & 20.5 & 86 & 2030 & 1970 & 10200 & & & & & \\
\hline & & & & & & TDT & - YIELDS & & & 6940 & 5690 & 20700 \\
\hline
\end{tabular}

MINIMUM CUTS FDR INCLUSIDN IN TDTAL YIELDS-- 320. CU8IC FEET AND 1500. 8DARD FEET

DWARF MISTLETDE INFECTIDN DID NDT DCCUR DURING THE RDTATIDN DF 130. YEARS.

MERCH. CU. FT. - TREES 6.0 INCHES D.8.H. AND LARGER TD 4.0-INCH TOP.

8D. FT. - TREES 10.0 INCHES D.8.H. AND LARGER TD VARIA8LE TDP LIMIT. 
YIELOS PER ACRE OF EVEN-AGEO STANOS OF PONDEROSA PINE

YIELOS PER ACRE OF EVEN-AGEO STANOS

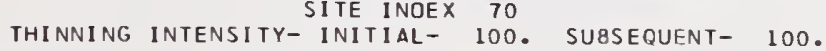

ENTIRE STANO BEFORE ANO AFTER THINNING

PERIOOIC INTERMEDIATE CUTS

\begin{tabular}{|c|c|c|c|c|c|c|c|c|c|c|c|c|}
\hline $\begin{array}{l}\text { STANO } \\
\text { AGE } \\
\text { (YEARS) }\end{array}$ & $\begin{array}{c}\text { TREES } \\
\text { NO. }\end{array}$ & $\begin{array}{l}\text { BASAL } \\
\text { AREA } \\
\text { SQ.FT. }\end{array}$ & $\begin{array}{l}\text { AVERAGE } \\
\text { O.8.H. } \\
\text { IN. }\end{array}$ & $\begin{array}{c}\text { AVERAGE } \\
\text { HEIGHT } \\
\text { FT. }\end{array}$ & $\begin{array}{l}\text { TOTAL } \\
\text { VOLUME } \\
\text { CU.FT. }\end{array}$ & $\begin{array}{c}\text { MERCHANT- } \\
\text { A8LE VOLUME } \\
\text { CU.FT. }\end{array}$ & $\begin{array}{c}\text { SAWTIMBER } \\
\text { VOLUME } \\
\text { BO.FT. }\end{array}$ & $\begin{array}{l}\text { TREES } \\
\text { NO. }\end{array}$ & $\begin{array}{l}\text { BASAL } \\
\text { AREA } \\
\text { SQ.FT. }\end{array}$ & $\begin{array}{l}\text { TOTAL } \\
\text { VOLUME } \\
\text { CU.FT. }\end{array}$ & $\begin{array}{l}\text { MERCHANT- } \\
\text { A8LE VOLUME } \\
\text { CU.FT. }\end{array}$ & $\begin{array}{l}\text { SAWTIMBER } \\
\text { VILUME } \\
\text { BD.FT. }\end{array}$ \\
\hline 30 & 950 & 119 & 4.8 & 25 & 1530 & 360 & 0 & & & & & \\
\hline 30 & 373 & 68 & 5.8 & 27 & 810 & 360 & 0 & 577 & 51 & 720 & 0 & 0 \\
\hline 40 & 370 & 96 & 6.9 & 36 & 1330 & 920 & 0 & & & & & \\
\hline 50 & 365 & 121 & 7.8 & 44 & 1970 & 1560 & 1000 & & & & & \\
\hline 50 & 239 & 94 & 8.5 & 45 & 1530 & 1290 & 1000 & 126 & 27 & 440 & 270 & 0 \\
\hline 60 & 237 & 114 & 9.4 & 51 & 2060 & 1820 & 2900 & & & & & \\
\hline 70 & 235 & 133 & 10.2 & 58 & 2820 & 2540 & 6000 & & & & & \\
\hline 70 & 154 & 100 & 10.9 & 59 & 2140 & 1950 & 5700 & 81 & 33 & 680 & 590 & 300 \\
\hline 80 & 154 & 117 & 11.8 & 65 & 2800 & 2570 & 9100 & & & & & \\
\hline 90 & 154 & 133 & 12.6 & 69 & 3460 & 3210 & 11900 & & & & & \\
\hline 90 & 104 & 100 & 13.3 & 70 & 2630 & 2460 & 9400 & 50 & 33 & 830 & 750 & 2500 \\
\hline 100 & 104 & 114 & 14.2 & 74 & 3200 & 3010 & 12000 & & & & & \\
\hline 110 & 104 & 129 & 15.1 & 78 & 3810 & 3600 & 15000 & & & & & \\
\hline 110 & 32 & 49 & 16.8 & 80 & 1490 & 1420 & 6400 & 72 & 80 & 2320 & 2180 & 8600 \\
\hline 120 & 32 & 58 & 18.3 & 83 & 1840 & 1770 & 8500 & & & & & \\
\hline 130 & 32 & 68 & 19.7 & 86 & 2210 & 2140 & 10800 & & & & & \\
\hline & & & & & & TOTA & YIELOS & & & 7200 & 5660 & 21900 \\
\hline
\end{tabular}

MINIMUM CUTS FOR INCLUSION IN TOTAL YIELOS-- 320. CU8IC FEET ANO 1500. BOARO FEET

OWARF MISTLETOE INFECTION OIO NOT OCCUR OURING THE ROTATION OF 130. YEARS.

MERCH. CU. FT. - TREES 6.0 INCHES 0.8.H. ANO LARGER TO 4.0-INCH TOP.

80. FT. - TREES 10.0 INCHES $0.8 . \mathrm{H}$. ANO LARGER TO VARIABLE TOP LIMIT.

YIELOS PER ACRE OF EVEN-AGEO STANOS OF PONOEKOSA PINE
SITE INOEX 70

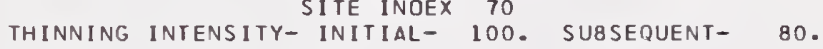

ENTIRE STANO BEFORE ANO AFTER THINNING

PERIDOIC INTERMEOIATE CUTS

\begin{tabular}{|c|c|c|c|c|c|c|c|c|c|c|c|c|}
\hline $\begin{array}{l}\text { STANO } \\
\text { AGE } \\
\text { (YEARS) }\end{array}$ & $\begin{array}{c}\text { TREES } \\
\text { NO. }\end{array}$ & $\begin{array}{l}\text { BASAL } \\
\text { AREA } \\
\text { SQ.FT. }\end{array}$ & $\begin{array}{l}\text { AVERAGE } \\
\text { O.8.H. } \\
\text { IN. }\end{array}$ & $\begin{array}{l}\text { AVERAGE } \\
\text { HEIGHT } \\
\text { FT. }\end{array}$ & $\begin{array}{l}\text { TOTAL } \\
\text { VOLUME } \\
\text { CU.FT. }\end{array}$ & $\begin{array}{c}\text { MERCHANT- } \\
\text { ABLE VOLUME } \\
\text { CU.FT. }\end{array}$ & $\begin{array}{l}\text { SAWTIMBER } \\
\text { VOLUME } \\
80 . F T .\end{array}$ & $\begin{array}{l}\text { TREES } \\
\text { NO. }\end{array}$ & $\begin{array}{l}\text { BASAL } \\
\text { AREA } \\
\text { SO.FT. }\end{array}$ & $\begin{array}{l}\text { TOTAL } \\
\text { VOLUME } \\
\text { CU.FT. }\end{array}$ & $\begin{array}{c}\text { MERCHANT- } \\
\text { ABLE VOLUME } \\
\text { CU.FT. }\end{array}$ & $\begin{array}{l}\text { SAWT IMBER } \\
\text { VOLUME } \\
\text { 8D.FT. }\end{array}$ \\
\hline 30 & 950 & 119 & 4.8 & 25 & 1510 & 0 & 0 & & & & & \\
\hline 30 & 374 & 28 & 3.7 & 23 & 410 & 0 & 0 & 576 & 91 & 1100 & 0 & 0 \\
\hline 40 & 372 & 59 & 5.4 & 32 & 820 & 290 & 0 & & & & & \\
\hline 50 & 332 & 79 & 6.6 & 40 & 1230 & 800 & 0 & & & & & \\
\hline 50 & 253 & 64 & 6.8 & 41 & 1000 & 670 & 0 & 79 & 15 & 230 & 130 & 0 \\
\hline 60 & 227 & 79 & 8.0 & 47 & 1350 & 1090 & 300 & & & & & \\
\hline 70 & 191 & 86 & 9.1 & 54 & 1630 & 1420 & 1700 & & & & & \\
\hline 70 & 191 & 86 & 9.1 & 54 & 1630 & 1420 & 1700 & 0 & 0 & 0 & 0 & 0 \\
\hline 80 & 156 & 87 & 10.1 & 60 & 1860 & 1670 & 3500 & & & & & \\
\hline 90 & 124 & 83 & 11.1 & 64 & 1960 & 1790 & 5500 & & & & & \\
\hline 90 & 124 & 83 & 11.1 & 64 & 1960 & 1790 & 5500 & 0 & 0 & 0 & 0 & 0 \\
\hline 100 & 95 & 76 & 12.1 & 68 & 1920 & 1770 & 6400 & & & & & \\
\hline 110 & 71 & 66 & 13.1 & 72 & 1780 & 1660 & 6300 & & & & & \\
\hline 110 & 37 & 40 & 14.0 & 73 & 1080 & 1010 & 4000 & 34 & 26 & 700 & 650 & 2300 \\
\hline 120 & 29 & 38 & 15.5 & 76 & 1090 & 1030 & 4400 & & & & & \\
\hline 130 & 21 & 33 & 16.9 & 79 & 970 & 1010 & 4200 & & & & & \\
\hline \multicolumn{10}{|c|}{ TOTAL YIELOS } & 3000 & 1660 & 6500 \\
\hline
\end{tabular}

MINIMUM CUTS FOR INCLUSION IN TOTAL YIELOS-- 320. CU8IC FEET ANO 1500. 80ARO FEET

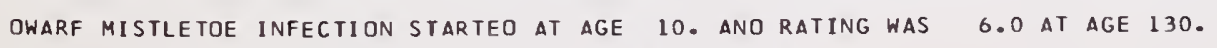

NOTE THAT NOT ALL SCHEOULEO THINNINGS WERE POSSIBLE.

MERCH. CU. FT. - TREES 6.0 INCHES 0.8.H. ANO LARGER TO 4.0-INCH TOP.

80. FT. - TREES 10.0 INCHES O.8.H. ANO LARGER TO VARIABLE TOP LIMIT. 
YIELDS PER ACRE OF EVEN-AGED STANDS OF PONDEROSA PINE SITE INDEX 70
THINNING INTENSITY- INITIAL- 100. SUBSEQUENT- 90.

ENTIRE STAND BEFORE AND AFTER THINNING

PERIODIC INTERMEDIATE CUTS

\begin{tabular}{|c|c|c|c|c|c|c|c|c|c|c|c|c|}
\hline $\begin{array}{l}\text { STAND } \\
\text { AGE } \\
\text { (YEARS) }\end{array}$ & $\begin{array}{l}\text { TREES } \\
\text { NO. }\end{array}$ & $\begin{array}{l}\text { 8ASAL } \\
\text { AREA } \\
\text { SQ.FT. }\end{array}$ & $\begin{array}{l}\text { AVERAGE } \\
0.8 \cdot H_{0} \\
\text { IN. }\end{array}$ & $\begin{array}{c}\text { AVERAGE } \\
\text { HEIGHT } \\
\text { FT. }\end{array}$ & $\begin{array}{l}\text { TOTAL } \\
\text { VOLUME } \\
\text { CU.FT. }\end{array}$ & $\begin{array}{l}\text { MERCHANT- } \\
\text { A8LE VOLUME } \\
\text { CU.FT. }\end{array}$ & $\begin{array}{l}\text { SAWT IMBER } \\
\text { VOLUME } \\
\text { BD.FT. }\end{array}$ & $\begin{array}{c}\text { TREES } \\
\text { NO. }\end{array}$ & $\begin{array}{l}\text { 8ASAL } \\
\text { AREA } \\
\text { SQ.FT. }\end{array}$ & $\begin{array}{l}\text { TOTAL } \\
\text { VOLUME } \\
\text { CU.FT. }\end{array}$ & $\begin{array}{c}\text { MERCHANT- } \\
\text { ABLE VOLUME } \\
\text { CU.FT. }\end{array}$ & $\begin{array}{l}\text { SAWIIMBE } \\
\text { VDLUME } \\
\text { BD.FT. }\end{array}$ \\
\hline $\begin{array}{l}30 \\
30\end{array}$ & $\begin{array}{l}950 \\
374\end{array}$ & $\begin{array}{r}119 \\
2 B\end{array}$ & $\begin{array}{l}4.8 \\
3.7\end{array}$ & $\begin{array}{l}25 \\
23\end{array}$ & $\begin{array}{r}1510 \\
410\end{array}$ & $\begin{array}{l}0 \\
0\end{array}$ & $\begin{array}{l}0 \\
0\end{array}$ & 576 & 91 & 1100 & 0 & 0 \\
\hline 40 & 372 & 59 & 5.4 & 32 & 820 & 290 & 0 & & & & & \\
\hline $\begin{array}{l}50 \\
50\end{array}$ & $\begin{array}{l}332 \\
289\end{array}$ & $\begin{array}{l}79 \\
71\end{array}$ & $\begin{array}{l}6.6 \\
6.7\end{array}$ & $\begin{array}{l}40 \\
41\end{array}$ & 1230 & $\begin{array}{l}\text { B00 } \\
730\end{array}$ & $\begin{array}{l}0 \\
0\end{array}$ & 43 & 8 & 130 & 70 & 0 \\
\hline 60 & 256 & 85 & 7.8 & 47 & 1450 & 1150 & 0 & & & & & \\
\hline $\begin{array}{l}70 \\
70\end{array}$ & $\begin{array}{l}215 \\
215\end{array}$ & $\begin{array}{l}91 \\
91\end{array}$ & $\begin{array}{l}\text { B. } 8 \\
8.8\end{array}$ & $\begin{array}{l}54 \\
54\end{array}$ & $\begin{array}{l}1720 \\
1720\end{array}$ & $\begin{array}{l}1480 \\
1480\end{array}$ & $\begin{array}{l}1500 \\
1500\end{array}$ & 0 & 0 & 0 & 0 & 0 \\
\hline 80 & 175 & 92 & 9.8 & 59 & 1950 & 1740 & 3200 & & & & & \\
\hline $\begin{array}{l}90 \\
90\end{array}$ & $\begin{array}{l}138 \\
138\end{array}$ & $\begin{array}{l}88 \\
\text { B B }\end{array}$ & $\begin{array}{l}10.8 \\
10.8\end{array}$ & $\begin{array}{l}64 \\
64\end{array}$ & $\begin{array}{l}2060 \\
2060\end{array}$ & $\begin{array}{l}1870 \\
1870\end{array}$ & $\begin{array}{l}5200 \\
5200\end{array}$ & 0 & 0 & 0 & 0 & 0 \\
\hline 100 & 106 & 81 & 11.8 & 68 & 2030 & 1870 & 6600 & & & & & \\
\hline $\begin{array}{l}110 \\
110\end{array}$ & $\begin{array}{l}79 \\
44\end{array}$ & $\begin{array}{l}71 \\
45\end{array}$ & $\begin{array}{l}12.8 \\
13.7\end{array}$ & $\begin{array}{l}72 \\
73\end{array}$ & $\begin{array}{l}18 B 0 \\
1220\end{array}$ & $\begin{array}{l}1750 \\
1140\end{array}$ & $\begin{array}{l}6500 \\
4500\end{array}$ & 35 & 26 & 660 & 610 & 2000 \\
\hline 120 & 34 & 42 & 15.1 & 76 & 1200 & 1140 & 4700 & & & & & \\
\hline 130 & 25 & 37 & 16.4 & 78 & 1090 & 1140 & 4600 & & & & & \\
\hline
\end{tabular}

MINIMUM CUTS FOR INCLUSION IN TOTAL YIELDS-- 320. CUBIC FEET AND 1500. 8OARO FEET

DWARF MISTLETOE INFECTION STARTED AT AGE 10. AND RATING HAS 6.0 AT AGE 130.

NOTE THAT NOT ALL SCHEDULED THINNINGS WERE POSSI8LE.

MERCH. CU. FT. - TREES 6.0 INCHES O.B.H. AND LARGER TO 4.0-INCH TOP.

8D. FT. - TREES 10.0 INCHES D.B.H. AND LARGER TO VARIABLE TOP LIMIT.

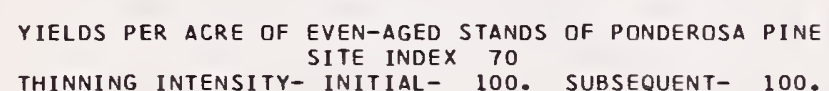

THINNING INTENSITY- INITIAL- 100 . SUBSEQUENT- 100.

ENTIRE STAND 8EFORE AND AFTER THINNING

PERIODIC INTERMEDIATE CUTS

\begin{tabular}{|c|c|c|c|c|c|c|c|c|c|c|c|c|}
\hline $\begin{array}{l}\text { STAND } \\
\text { AGE } \\
\text { (YEARS) }\end{array}$ & $\begin{array}{c}\text { TREES } \\
\text { NO. }\end{array}$ & $\begin{array}{l}\text { 8ASAL } \\
\text { AREA } \\
\text { SQ.FT. }\end{array}$ & $\begin{array}{c}\text { AVERAGE } \\
\text { D.B.H. } \\
\text { IN. }\end{array}$ & $\begin{array}{c}\text { AVERAGE } \\
\text { HEIGHT } \\
\text { FT. }\end{array}$ & $\begin{array}{l}\text { TOTAL } \\
\text { VOLUME } \\
\text { CU.FT. }\end{array}$ & $\begin{array}{l}\text { MERCHANT- } \\
\text { A8LE VOLUME } \\
\text { CU.FT. }\end{array}$ & $\begin{array}{c}\text { SAWT IMBER } \\
\text { VDLUME } \\
\text { 8D.FT. }\end{array}$ & $\begin{array}{c}\text { TREES } \\
\text { NO. }\end{array}$ & $\begin{array}{l}\text { 8ASAL } \\
\text { AREA } \\
\text { SQ.FT. }\end{array}$ & $\begin{array}{r}\text { TOTAL } \\
\text { VOLUME } \\
\text { CU.FT. }\end{array}$ & $\begin{array}{l}\text { MERCHANT- } \\
\text { ABLE VOLUME } \\
\text { CU.FT. }\end{array}$ & $\begin{array}{l}\text { SAWTIMBER } \\
\text { VOLUME } \\
\text { BD.FT. }\end{array}$ \\
\hline 30 & 950 & 119 & 4.8 & 25 & 1510 & 0 & 0 & & & & & \\
\hline 30 & 374 & 28 & 3.7 & 23 & 410 & 0 & 0 & 576 & 91 & 1100 & 0 & 0 \\
\hline 40 & 372 & 59 & 5.4 & 32 & 820 & 290 & 0 & & & & & \\
\hline 50 & 332 & 79 & 6.6 & 40 & 1230 & 800 & 0 & & & & & \\
\hline 50 & 327 & $7 \mathrm{~B}$ & 6.6 & 40 & 1210 & 790 & 0 & 5 & 1 & 20 & 10 & 0 \\
\hline 60 & $2 B 4$ & 92 & 7.7 & 47 & 1570 & 1230 & 0 & & & & & \\
\hline 70 & 238 & 98 & 8.7 & 53 & 1860 & 1590 & 1500 & & & & & \\
\hline 70 & 238 & 98 & 8.7 & 53 & 1860 & 1590 & 1500 & 0 & 0 & 0 & 0 & 0 \\
\hline 80 & 194 & 98 & 9.6 & 59 & 2060 & 1830 & 3100 & & & & & \\
\hline 90 & 153 & 92 & 10.5 & 64 & 2140 & 1940 & 4900 & & & & & \\
\hline 90 & 153 & 92 & 10.5 & 64 & 2140 & 1940 & 4900 & 0 & 0 & 0 & 0 & 0 \\
\hline 100 & 117 & 83 & 11.4 & 68 & $20 \mathrm{OBO}$ & 1900 & 6500 & & & & & \\
\hline 110 & 87 & 73 & 12.4 & 71 & 1940 & 1790 & 6600 & & & & & \\
\hline 110 & 53 & 50 & 13.2 & 72 & 1360 & 1270 & 4800 & 34 & 23 & 580 & 520 & $1 \mathrm{BOO}$ \\
\hline 120 & 41 & 47 & 14.5 & 75 & 1330 & 1250 & 5100 & & & & & \\
\hline 130 & 30 & 41 & 15.8 & 78 & 1200 & 1270 & 4900 & & & & & \\
\hline \multicolumn{10}{|c|}{ TOTAL YIELDS } & 2900 & 1790 & 6700 \\
\hline
\end{tabular}

MINIMUM CUTS FOR INCLUSION IN TOTAL YIELDS-- 320. CUBIC FEET AND 1500. 80ARD FEET

DWARF MISTLETOE INFECTION STARTED AT AGE 10. AND RATING WAS 6.0 AT AGE 130.

NOTE THAT NOT ALL SCHEOULEO THINNINGS WERE POSSI8LE.

MERCH. CU. FT. - TREES 6.0 INCHES D.8.H. AND LARGER TO 4.0-INCH TOP.

BO. FT. - TREES 10.0 INCHES D.8.H. AND LARGER TO VARIA8LE TOP LIMIT. 
YIELDS PER ACRE OF EVEN-AGED STANDS OF PDNDEROSA PINE

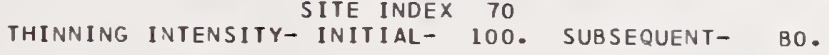

\section{ENTIRE STAND BEFORE AND AFTER THINNING}

PERIDDIC INTERMEDIATE CUTS

\begin{tabular}{|c|c|c|c|c|c|c|c|c|c|c|c|c|}
\hline $\begin{array}{l}\text { STAND } \\
\text { AGE } \\
\text { (YEARS) }\end{array}$ & $\begin{array}{c}\text { TREES } \\
\text { NO. }\end{array}$ & $\begin{array}{l}\text { BASAL } \\
\text { AREA } \\
\text { SQ.FT. }\end{array}$ & $\begin{array}{c}\text { AVERAGE } \\
\text { D. B.H. } \\
\text { IN. }\end{array}$ & $\begin{array}{c}\text { AVERAGE } \\
\text { HEIGHT } \\
\text { FT. }\end{array}$ & $\begin{array}{l}\text { TOTAL } \\
\text { VOLUME } \\
\text { CU.FT. }\end{array}$ & $\begin{array}{c}\text { MERCHANT- } \\
\text { ABLE VDLUME } \\
\text { CU.FT. }\end{array}$ & $\begin{array}{l}\text { SAWT IMBER } \\
\text { VDLUME } \\
\text { BD.FT. }\end{array}$ & $\begin{array}{l}\text { TREES } \\
\text { NO. }\end{array}$ & $\begin{array}{l}\text { BASAL } \\
\text { AREA } \\
\text { SQ.FT. }\end{array}$ & $\begin{array}{l}\text { TDTAL } \\
\text { VOLUME } \\
\text { CU.FT. }\end{array}$ & $\begin{array}{c}\text { MERCHANT- } \\
\text { ABLE VDLUME } \\
\text { CU.FT. }\end{array}$ & $\begin{array}{l}\text { SAWTIMBER } \\
\text { VOLUME } \\
\text { BD.FT. }\end{array}$ \\
\hline 5D & 575 & 121 & 6.2 & 40 & 1920 & 1060 & 0 & & & & & \\
\hline 50 & 575 & 121 & 6.2 & 40 & $192 \mathrm{D}$ & $106 D$ & 0 & 0 & 0 & 0 & 0 & 0 \\
\hline 60 & 447 & 116 & 6.9 & 46 & 2020 & 1400 & 0 & & & & & \\
\hline 70 & 337 & 106 & 7.6 & 53 & 2D4D & $15 B D$ & 0 & & & & & \\
\hline 70 & 337 & 106 & 7.6 & 53 & 2040 & 1580 & 0 & D & 0 & 0 & 0 & 0 \\
\hline BO & 246 & 95 & B. 4 & 59 & 1960 & 1640 & $11 \mathrm{DO}$ & & & & & \\
\hline 90 & 174 & 80 & 9.2 & 63 & $1 B 1 D$ & 1580 & 2000 & & & & & \\
\hline 90 & 174 & 80 & 9.2 & 63 & $1 B 1 D$ & $15 B D$ & 2000 & D & 0 & 0 & 0 & 0 \\
\hline $10 D$ & 121 & 67 & 10.1 & 67 & $164 D$ & 1470 & 3000 & & & & & \\
\hline 110 & 85 & 57 & 11.1 & 71 & 1480 & 1350 & 4100 & & & & & \\
\hline 110 & 52 & 40 & 11.9 & 71 & 1060 & $9 B D$ & 3500 & 33 & 17 & $42 \mathrm{D}$ & 370 & 600 \\
\hline 120 & 40 & 39 & 13.3 & 75 & 1070 & 1000 & 3800 & & & & & \\
\hline 130 & 29 & 34 & 14.7 & 77 & $99 D$ & $9 B D$ & 3800 & & & & & \\
\hline & & & & & & TDTA & YIELDS & & & 1410 & 1350 & 3800 \\
\hline
\end{tabular}

MINIMUM CUTS FOR INCLUSION IN TOTAL YIELDS-- 32D. CUBIC FEET AND 1500. BDARD FEET

DWARF MISTLETDE INFECTION STARTED AT AGE 10. AND RATING WAS 6.0 AT AgE 130.

NOTE THAT NOT ALL SCHEDULED THINNINGS WERE POSSIBLE.

MERCH. CU. FT. - TREES 6.D INCHES D.8.H. AND LARGER TO 4.D-INCH TDP.

BD. FT. - TREES ID.O INCHES D.B.H. AND LARGER TO VARIABLE TDP LIMIT.

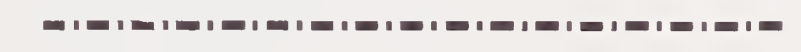

YIELDS PER ACRE DF EVEN-AGED STANDS DF PDVDEROSA PINE

SITE INDEX 70

THINNING INTENSITY- INITIAL- 100. SUBSEQUENT- 90.

ENTIRE STAND BEFDRE AND AFTER THINNING

PERIODIC INTERMEDIATE CUTS

\begin{tabular}{|c|c|c|c|c|c|c|c|c|c|c|c|c|}
\hline STAND & & BASAL & $\begin{array}{c}\text { AVERAGE } \\
D . B . H .\end{array}$ & $\begin{array}{l}\text { AVERAGE } \\
\text { HEIGHT }\end{array}$ & $\begin{array}{r}\text { TDTAL } \\
\text { VDLUME }\end{array}$ & $\begin{array}{l}\text { MERCHANT- } \\
\text { ABLE VOLUME }\end{array}$ & SAWT IMBER & & BASAL & TDTAL & MERCHANT - & SAWT IMBEF \\
\hline $\begin{array}{c}\text { AGE } \\
\text { (YEARS) }\end{array}$ & $\begin{array}{l}\text { TREES } \\
\text { NO. }\end{array}$ & $\begin{array}{l}\text { AREA } \\
\text { SQ.FT. }\end{array}$ & $\begin{array}{c}\mathrm{D}_{. \mathrm{B} \cdot \mathrm{H}} \\
\text { IN. }\end{array}$ & $\begin{array}{l}\text { HE I GHT } \\
\text { FT. }\end{array}$ & $\begin{array}{l}\text { VDLUME } \\
\text { CU.FT. }\end{array}$ & $\begin{array}{c}\text { ABLE VOLUME } \\
\text { CU.FT. }\end{array}$ & $\begin{array}{l}\text { VOLUME } \\
\text { BD.FT. }\end{array}$ & $\begin{array}{l}\text { TREES } \\
\text { VD. }\end{array}$ & $\begin{array}{c}\text { AREA } \\
\text { SQ.FT. }\end{array}$ & $\begin{array}{l}\text { VOLUME } \\
\text { CU.FT. }\end{array}$ & $\begin{array}{l}\text { ABLE VDLUME } \\
\text { CU.FT. }\end{array}$ & $\begin{array}{l}\text { VDLUME } \\
\text { BD.FT. }\end{array}$ \\
\hline 50 & 575 & 121 & 6.2 & 40 & 1920 & 1060 & 0 & & & & & \\
\hline 50 & 575 & 121 & 6.2 & 40 & 1920 & 1060 & 0 & 0 & 0 & 0 & D & 0 \\
\hline $6 D$ & 447 & 116 & 6.9 & 46 & 2020 & 1400 & 0 & & & & & \\
\hline 70 & 337 & 106 & 7.6 & 53 & 2040 & 1580 & 0 & & & & & \\
\hline $7 D$ & 337 & 106 & 7.6 & 53 & 2040 & 1580 & 0 & 0 & 0 & 0 & 0 & 0 \\
\hline Bo & 246 & 95 & B. 4 & 59 & 1960 & 1640 & 1100 & & & & & \\
\hline $9 D$ & 174 & BD & 9.2 & 63 & 1810 & $15 B 0$ & 2000 & & & & & \\
\hline 90 & 174 & 80 & 9.2 & 63 & 1810 & 1580 & 2000 & 0 & 0 & 0 & D & 0 \\
\hline 100 & 121 & 67 & 10.1 & 67 & 1640 & 1470 & 3000 & & & & & \\
\hline 110 & B5 & 57 & 11.1 & 71 & $14 \mathrm{BD}$ & 1350 & 4100 & & & & & \\
\hline 110 & 60 & 45 & 11.7 & 71 & 1180 & 1080 & 3800 & 25 & 12 & 300 & 270 & 300 \\
\hline $12 \mathrm{D}$ & 45 & 41 & 13.0 & 74 & 1150 & 1070 & 4000 & & & & & \\
\hline 130 & 32 & 36 & 14.3 & 77 & 1030 & 1080 & 3900 & & & & & \\
\hline
\end{tabular}

MINIMUM CUTS FOR INCLUSION IN TDTAL YIELDS-- 320. CUBIC FEET AND 1500. BOARD FEET

DHARF MISTLETDE INFECTIDN STARTED AT AGE 10. AND RATING WAS 6.0 AT AGE 130.

NDTE THAT NDT ALL SCHEDULED THINNINGS WERE PDSSIBLE.

MERCH. CU. FT. - TREES 6.0 INCHES D.B.H. AND LARGER TO $4.0-I N C H$ TDP.

BD. FT. - TREES 10.0 INCHES D.B.H. AND LARGER TO VARIABLE TDP LIMIT. 
YIELDS PER ACRE OF EVEN-AGEO STANDS OF PONDEROSA PINE

THINNING INTENSITY- SITE INDEX 70

ENTIRE STAND BEFORE AND AFTER THINNING

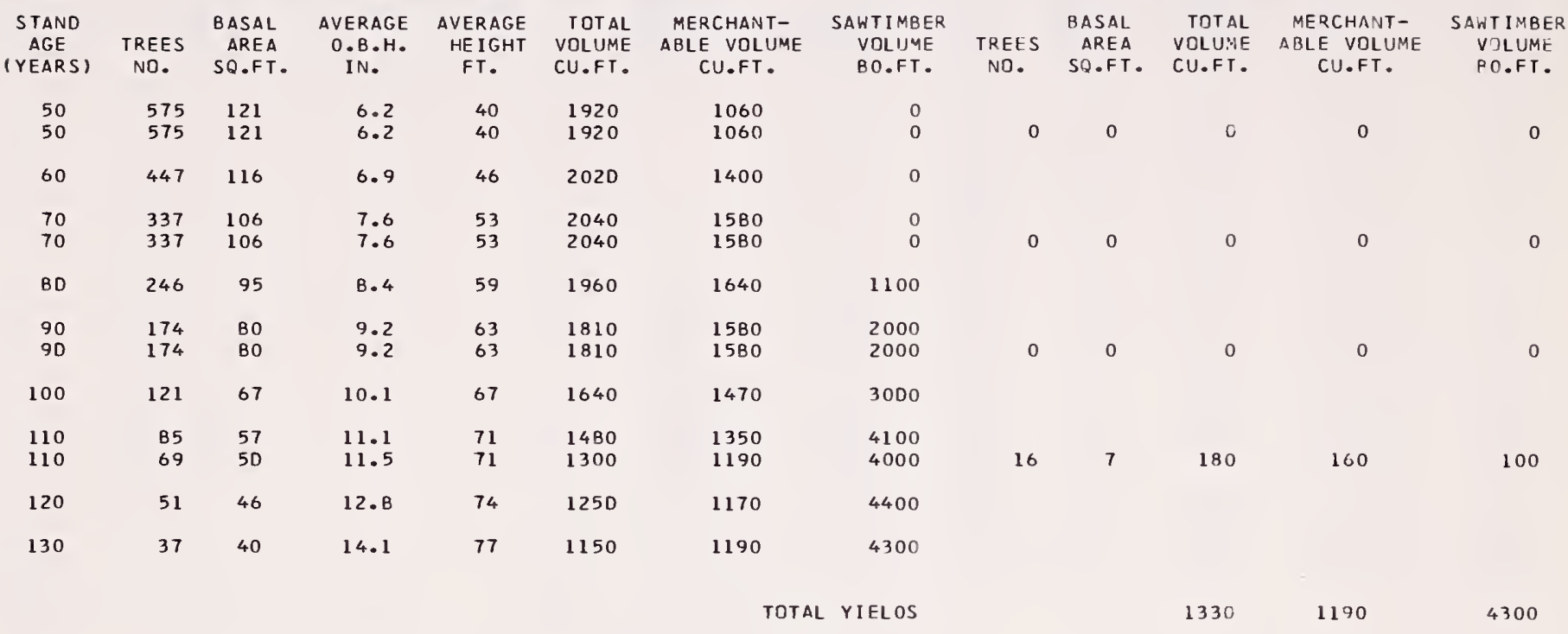

MINIMUM CUTS FOR INCLUSION IN TOTAL YIELOS-- 320. CUBIC FEET ANO 1500. BOARD FEET OWARF MISTLETOE INFECTION STARTEO AT AGE 10. AND RATING WAS 6.0 AT AGE 130.

NOTE THAT NOT ALL SCHEOULEO THINNING WERE POSSIBLE.

MERCH. CU. FT. - TREES 6.0 INCHES 0.B.H. AND LARGER TO 4.0 -INCH TOP.

BO. FT. - TREES 10.0 INCHES O.B.H. AND LARGER TO VARIABLE TOP LIMIT.

Agriculture-CSU, Ft. Collins

16 

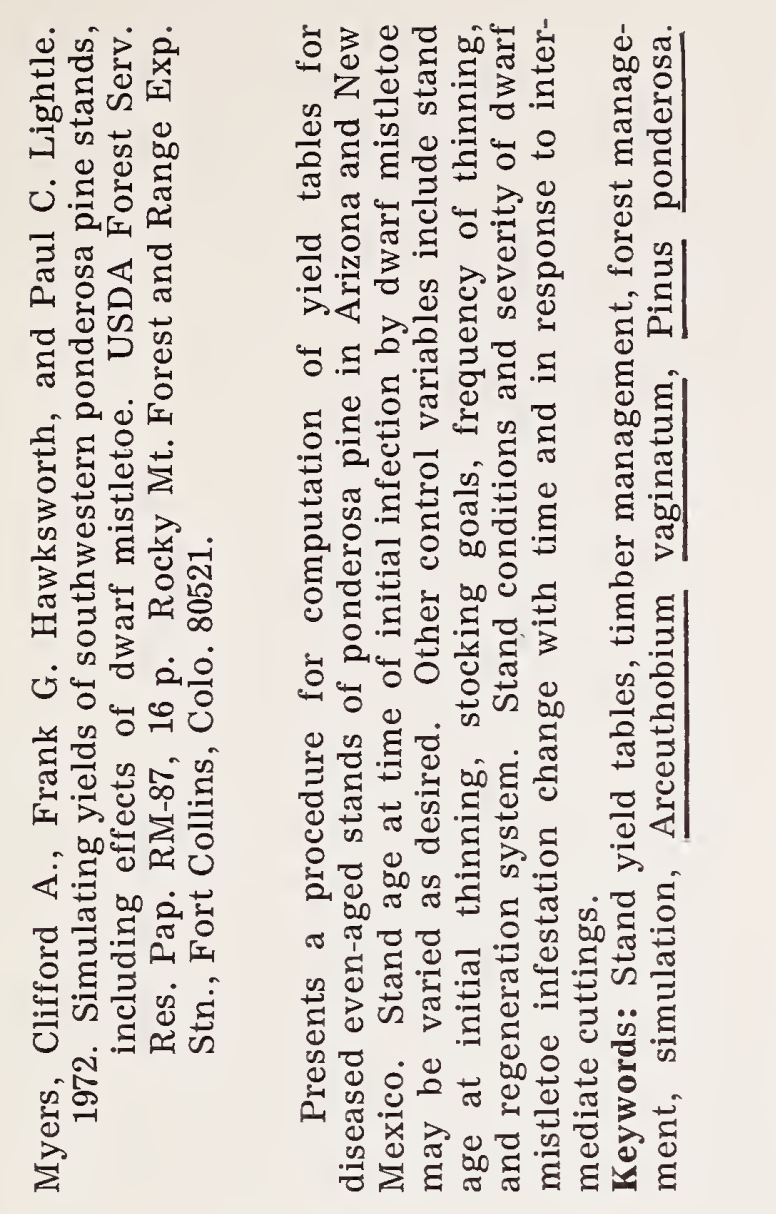

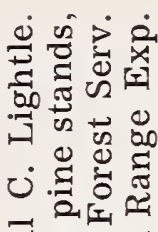

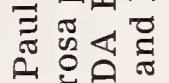

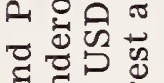

क

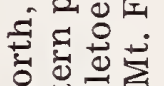

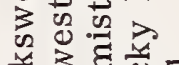

를

表苗

ن

를 务

政记

-

ব苛

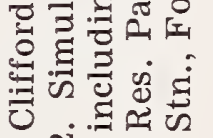

พํํㄴ

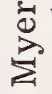

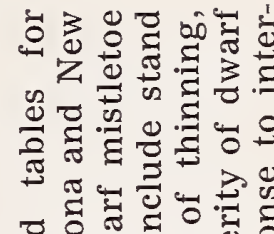

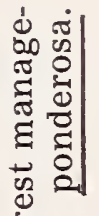

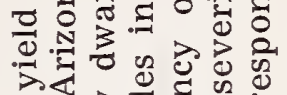

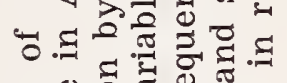

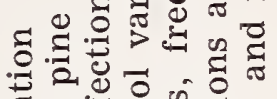

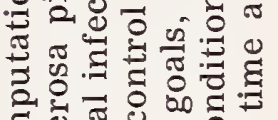

总路|

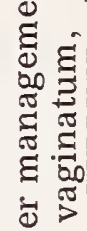

हैं

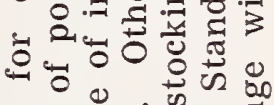

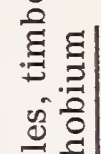

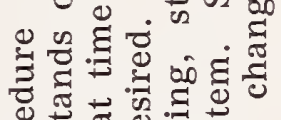

ठ犬

焉

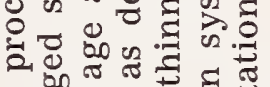

๙

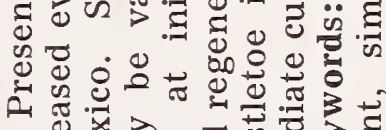

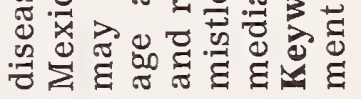

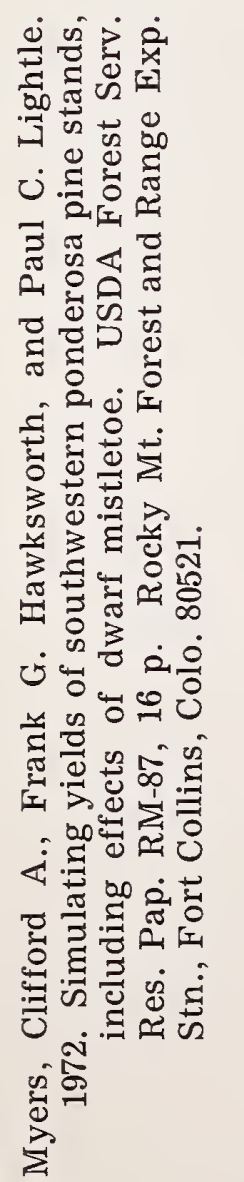

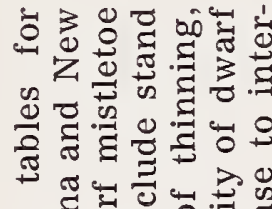

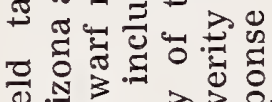

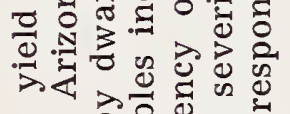

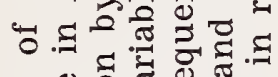

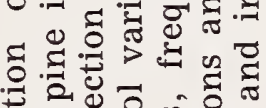

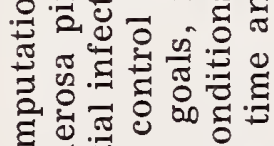

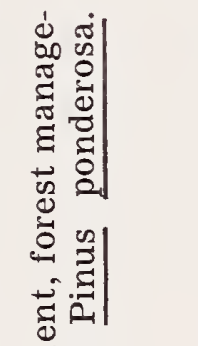

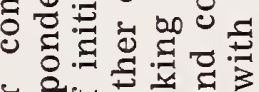

की

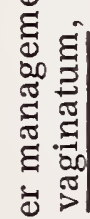

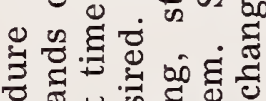

ठृ

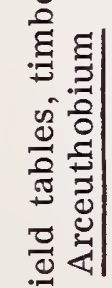

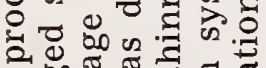

is

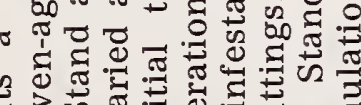

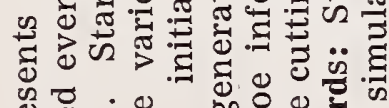

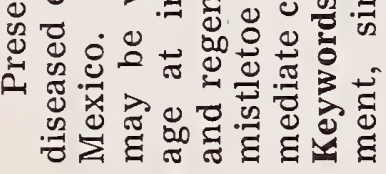

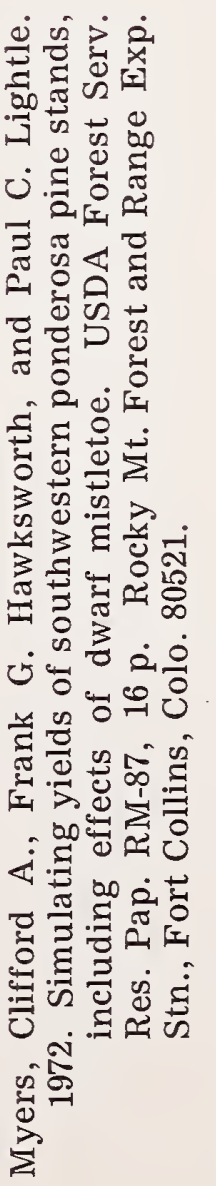

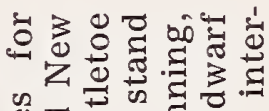

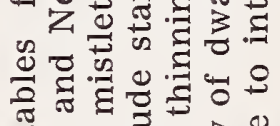

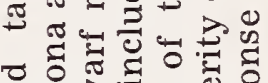

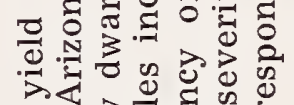

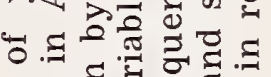

도월

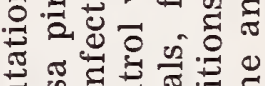

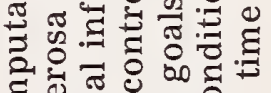

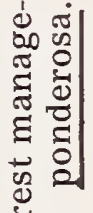

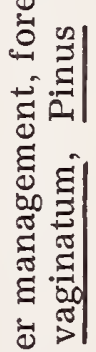

跣.

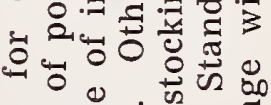

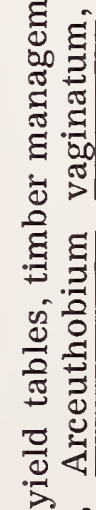

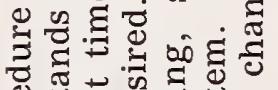

ठู

엉

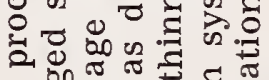

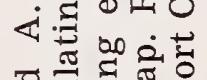

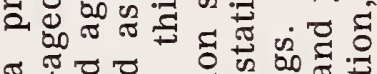

๓

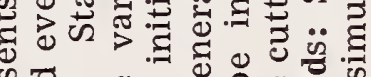

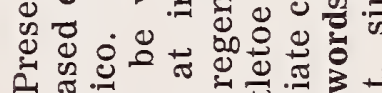

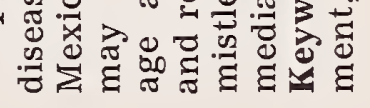




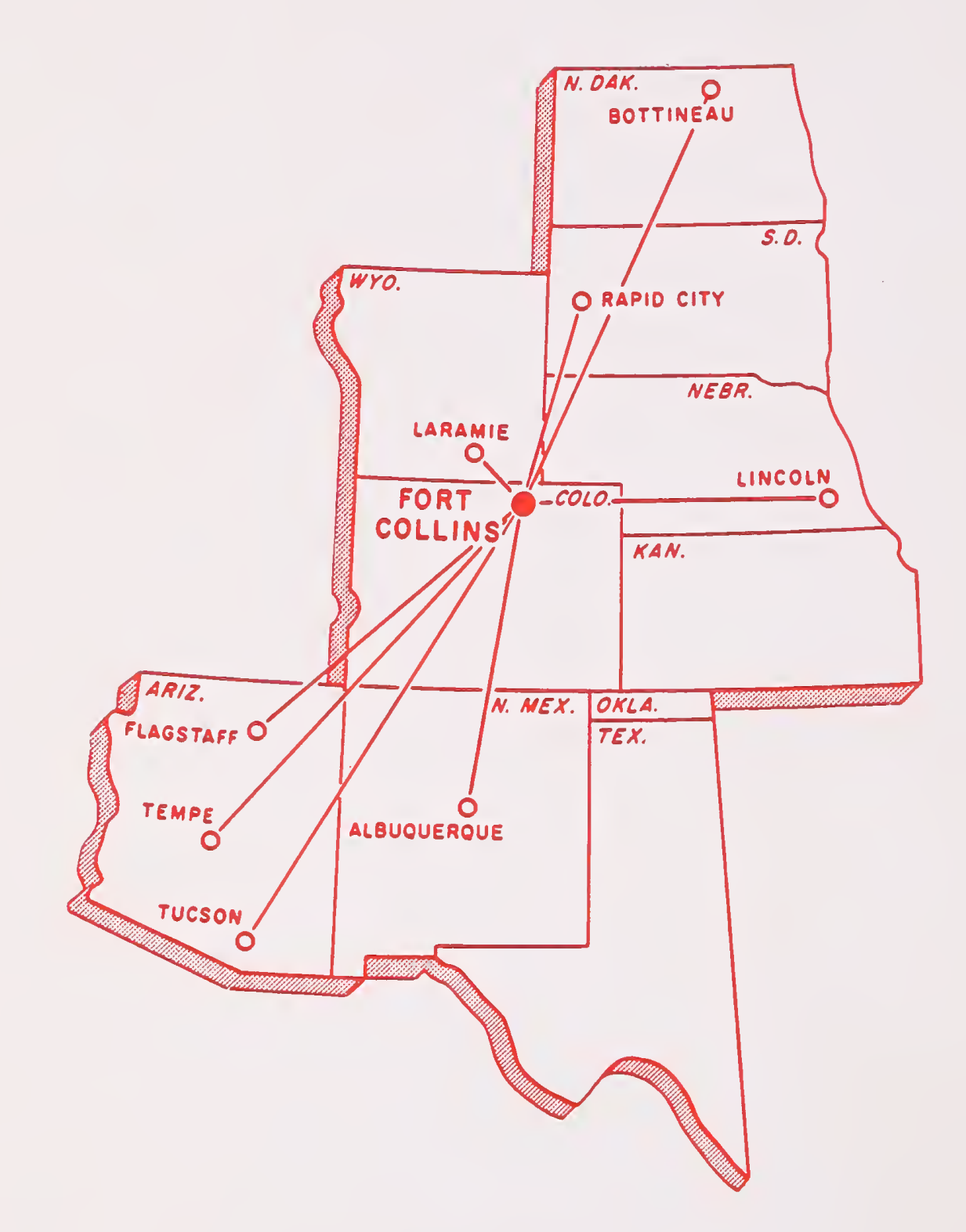

